\title{
REVIEW
}

\section{Cerebral Small Vessel Disease in Sporadic and Familial Alzheimer Disease}

\author{
Rajesh N. Kalaria* ${ }^{\dagger}$ and Diego Sepulveda-Falla
}

From the Neurovascular Research Group, * Translational and Clinical Research Institute, Newcastle University, Newcastle upon Tyne, United Kingdom; the Department of Human Anatomy, ${ }^{\dagger}$ College of Health Sciences, University of Nairobi, Nairobi, Kenya; and the Institute of Neuropathology, ${ }^{\ddagger}$ University Medical Center Hamburg-Eppendorf, Hamburg, Germany

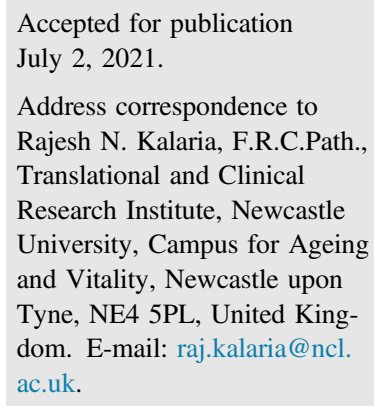

\begin{abstract}
Alzheimer disease $(A D)$ is the most common cause of dementia. Biological definitions of AD are limited to the cerebral burden of amyloid $\beta$ plaques, neurofibrillary pathology, and neurodegeneration. However, current evidence suggests that various features of small vessel disease (SVD) are part of and covertly modify both sporadic and familial AD. Neuroimaging studies suggest that white matter hyperintensities explained by vascular mechanisms occurs frequently in the AD spectrum. Recent advances have further emphasized that frontal periventricular and posterior white matter hyperintensities are associated with cerebral amyloid angiopathy in familial AD. Although whether SVD markers precede the classically recognized biomarkers of disease is debatable, post-mortem studies show that SVD pathology incorporating small cortical and subcortical infarcts, microinfarcts, microbleeds, perivascular spacing, and white matter attenuation is commonly found in sporadic as well as in mutation carriers with confirmed familial AD. Age-related cerebral vessel pathologies such as arteriolosclerosis and cerebral amyloid angiopathy modify progression or worsen risk by shifting the threshold for cognitive impairment and AD dementia. The incorporation of SVD as a biomarker is warranted in the biological definition of AD. Therapeutic interventions directly reducing the burden of brain amyloid $\beta$ have had no major impact on the disease or delaying cognitive deterioration, but lowering the risk of vascular disease seems the only rational approach to tackle both early- and late-onset $A D$ dementia. (Am J Pathol 2021, 191: 1888-1905; https://doi.org/10.1016/j.ajpath.2021.07.004)
\end{abstract}

The most common cause of age-related dementia is the multifactorial Alzheimer disease (AD). Although $<5 \%$ of biologically defined $\mathrm{AD}$ is thought to be familial in nature, even this proportion exhibits high phenotypic variability that can be modified by lifestyle or environmental factors. Late-onset $\mathrm{AD}$ is pathologically confirmed by the presence of extracellular amyloid $\beta(\mathrm{A} \beta)$ plaques, intracellular hyperphosphorylated tau, and neuron (or synaptic) loss. ${ }^{1}$ Early-onset or familial AD bears similar biological features, although typically, the hallmark pathology accrues considerably before 65 years of age. Clinical AD patients predominantly present with an insidious progressive irreversible amnesia and global cognitive decline in the absence of overt vascular disease. However, numerous post-mortem studies show that vast majority of patients diagnosed with $\mathrm{AD}$ dementia invariably have cerebral vascular pathology above and beyond normally aging healthy individuals. ${ }^{2-4}$ Many of the brain vascular changes are attributed to covert or silent cerebral small vessel disease (SVD). SVD features involving intracranial vessels $<1 \mathrm{~mm}$ in diameter may be acquired subsequent to the initial clinical diagnosis of $\mathrm{AD}$ but most likely result from long-standing hypertensive or other vascular disease, or from age-related intracranial microvascular pathology.

Supported by Alzheimer's Research UK grant ARUK PG2013-22; Medical Research Council, UK grant MRC, G0500247 (R.N.K.); and US National Institute of Neurological Disorders and Stroke and National Institute on Aging cofunded grant RF1NS110048 (D.S.-F.).

Disclosures: None declared.

This article is part of a review series on small blood vessel disease in the brain addressing current knowledge, new mechanisms, biomarkers, and therapeutic approaches. 
Though cerebral SVD independently contributes to morbidity, disability, and mortality, several studies have confirmed that SVD also adds to or modifies progression to dementia such that the threshold for impairment is reached earlier. ${ }^{6,7}$ For example, in the Nun study, SVD type of pathology in the form of lacunar infarcts in the basal ganglia, thalamus, or deep white matter (WM) was described to be associated with a higher prevalence of dementia. ${ }^{8}$ The presence of small vessel changes in clinically diagnosed and pathologically confirmed $\mathrm{AD}$ is not necessarily denied, ${ }^{9}$ but deciphering whether vascular brain injury occurs prior to or concomitantly with neurodegenerative changes, has become a burning issue in $\mathrm{AD}$ research.

This review discusses the current evidence of SVD in early- and late-onset $\mathrm{AD}$, and evaluate its contribution in the spectrum of $\mathrm{AD}$. It also appraises whether early-onset $\mathrm{AD}$ cases support the proposal that prior vascular dysfunction is part of the biomarker profile of AD. This is timely because it is strikingly clear that reducing brain $A \beta$ overload via any treatment intervention has not had a substantial impact on improving cognition, ${ }^{10}$ but lowering the severity or risk of vascular disease seems the worthwhile option to reduce the incidence of $\mathrm{AD}$ dementia.

\section{Epidemiology and Vascular Risk Factors in AD}

Although conscious efforts are made to exclude the presence of overt vascular disease in the diagnosis of $\mathrm{AD}$ dementia, reasonable evidence suggests that sporadic $\mathrm{AD}$ is associated with pre-existing or late acquired vascular risk factors. These include hypertension, diabetes mellitus, hypercholesterolemia, obesity, metabolic syndrome, and atherosclerosis; all collectively promote morbidity and specifically increase the probability of clinical AD diagnosis. Current systematic reviews and recent meta-analyses have identified hypertension in midlife, high body mass index in late life, hyperhomocysteinemia, diabetes, head trauma, and orthostatic hypotension to be most strongly associated with dementia or $\mathrm{AD} .{ }^{11-14}$ In addition, vascular risk factors promote conversion of mild cognitive impairment to frank dementia. ${ }^{15}$

Blood pressure is one of the most widely evaluated risk factors for dementia and $\mathrm{AD}$ in particular. Hypertension is a risk for WM damage as well as clinically covert lesions such as arteriolosclerosis, microbleeds, microinfarcts, infarcts, endothelial damage, and vascular inflammation. ${ }^{13,16-19}$ Although nondemented, normally aging individuals have histories of hypertension, large cohort studies suggest an association between systolic hypertension $(>160 \mathrm{~mm} \mathrm{Hg})$ in midlife and lateonset $\mathrm{AD}$ by a risk of $18 \%$ to $25 \%{ }^{20}$ or decreased risk of $\mathrm{AD}$ in the short term, possibly due to reverse causation. ${ }^{21}$ Blood pressure variability, albeit visit-to-visit or day-to-day, is also associated with progression of $\mathrm{AD},{ }^{22}$ and optimal blood pressure management appears to be important for prevention of dementia. ${ }^{23}$ The case for hypertension is further supported by a recent meta-analysis that explored the association of incident
$\mathrm{AD}$ with the use of five antihypertensive medications. ${ }^{24} \mathrm{High}$ systolic blood pressure $(>140 \mathrm{~mm} \mathrm{Hg}$ ) with a median followup of 7 to 22 years in those using any antihypertensive agent had reduced risk for developing $\mathrm{AD}$ (HR, 0.8; 95\% CI, 0.7 to 1.0) compared with those not on any antihypertensive agent. There were no significant differences between one drug class versus all others on risk of dementia. This indicates that certain protective measures against cardiovascular pathology appear beneficial in $\mathrm{AD}$, although the use of antihypertensives in secondary prevention of what is described as pure $\mathrm{AD}$ seems to be unclear. ${ }^{25}$ Findings from other longitudinal studies such as Atherosclerosis Risk in Communities (ARIC) ${ }^{26}$ and SPRINT MIND $^{27}$ suggest that intensive blood pressure control would be beneficial for the risk of dementia and AD. Long-term hypertension may have a major role in subclinical cerebral SVD across subtypes and brain regions highlighting the need to recognize and treat hypertension early in life. ${ }^{18}$ It is not unlikely that long-standing increase or variability in blood pressure may disrupt vasoregulatory functions, promote blood-brain barrier (BBB) damage, and cause neurodegeneration. ${ }^{28}$ Each vascular factor or collectively all, in different combinations, may unevenly alter the vasculature of the body or brain to cause distortions in normal structure and function, and potentially induce a chronic cerebral hypoperfusive state in old age. ${ }^{29}$

Whether hypertension per se substantially increases $\mathrm{AD}$ pathology is still not clear. In the Honolulu-Asia Aging Study (HAAS), midlife systolic and diastolic blood pressures were associated with an increased number of neuritic plaques and neurofibrillary pathology, ${ }^{30}$ whereas clinical studies showed that higher pulse pressure was associated with cerebral amyloidosis in the presence of neurodegeneration and progression to dementia and increased plasma $A \beta$ concentrations. ${ }^{31}$ Another study showed that medicated hypertensives exhibited less $\mathrm{AD}$ pathology. ${ }^{32}$ In the Religious Orders Study and the Rush Memory and Aging Project (RUSH) cohort, association between higher systolic blood pressure, albeit in late-life, was also associated with higher tangle burden. ${ }^{33}$ Well-designed longitudinal prospective studies with post-mortem examination and a treatment intervention to control vascular risk factors by demonstrating reduction in $\mathrm{AD}$ pathology and neuronal atrophy could address this question.

\section{Spectrum of SVD Pathology in AD}

Cerebrovascular pathology corresponding to most radiologically defined lesions is common in late-onset AD (Table 1). Although there is uncertainty whether Auguste Deter ${ }^{34}$ developed early- or late-onset $\mathrm{AD}$, it is intriguing that Alzheimer had described vascular changes including neovascularization in this original case. Numerous studies $^{3,4,35-38}$ have now reported that patterns of pure neuritic plaque and neurofibrillary tangle pathology are not the norm in pathologically diagnosed AD (Figure 1). Small lesions including lacunar infarcts, microinfarcts, hemosiderin 
deposition or microbleeds, arteriosclerosis, cerebral amyloid angiopathy (CAA), and arteriosclerotic leukoencephalopathy, or WM attenuation, are recorded, but large infarcts $(>1 \mathrm{~cm}$ in diameter) tend to be selected out from such cohorts. ${ }^{3}$ However, in a recent analysis from several centers, nearly $20 \%$ of AD subjects exhibited large infarcts. ${ }^{39}$ Findings from the National Alzheimer's Coordinating Centers showed that whereas only $32 \%$ of the $\mathrm{AD}$ cases reported cerebrovascular disease, SVD in terms of both parenchymal and vessel pathologies included lacunes in $20 \%$, multiple microinfarcts in $20 \%$, arteriosclerotic leukoencephalopathy in $9 \%$, hemorrhages in $7 \%$, atherosclerosis in $40 \%$, arteriolosclerosis in $35 \%$, and CAA in $41 \%$ of $\mathrm{AD}$ cases. Overall, various features of SVD pathology were present in up to $80 \%$ of the $4629 \mathrm{AD}$ autopsies. ${ }^{4}$ In other clinicopathologic studies, even greater proportions of SVD pathology ${ }^{40,41}$ were evident. In addition, the authors have reported high frequencies (approximately $100 \%$ ) of microvascular degeneration in prospectively assessed AD subjects. ${ }^{42,43}$ Remarkably, familial AD bears various features of SVD including severe WM attenuation and infarcts, although reporting such lesions was not the intent of previous studies, which focused on patterns of $A \beta$ deposition in the parenchyma and intracerebral vessels. ${ }^{44,45}$ In fact, a large study in familial AD cases determined that WM hyperintensities (WMH) are a core feature in familial AD pathology. ${ }^{46}$ In a South African subject with presenilin 1 (PSEN1) Ile143Met mutation, border zone infarcts, microinfarcts, arteriolosclerosis, perivascular spaces, and severe WM attenuation were also noted. ${ }^{47}$ Similarly, in the large Colombian PSEN1 Glu280Ala kindred ${ }^{48}$ severe SVD pathology not necessarily attributed to CAA was noted (D. Sepulveda-Falla, R.N. Kalaria, unpublished data).

Besides the inherent inconsistencies in reporting of SVD lesions across different centers, there is also an apparent mismatch or perhaps under-reporting of generally low prevalence of cardiovascular disease or relevant risk factors compared with degrees of SVD pathology in AD (and other neurodegenerative disorders such as Lewy body disease). ${ }^{4}$ In a recent study, ${ }^{49}$ clinical hypertensive disease or diabetes mellitus was recorded to be $10 \%$ lower, yet pathologic features of systemic vascular disease including moderate-to-severe coronary stenosis and variable infarction were up in $50 \%$ of the cases at post-mortem examination. Subclinical disease including cardiac dysfunction increases the risk of dementia. $^{14,50}$

Individuals diagnosed with $\mathrm{AD}$ in the community at large also tend to have greater vascular pathology compared with those from memory clinics. ${ }^{2,51}$ Normally aging communitydwelling older persons have some brain changes, and those with dementia often have multiple brain pathologies. However, cerebrovascular disease in $\mathrm{AD}$ patients increases the risk of developing clinical dementia and is additive, ${ }^{52}$ taking lower burdens of $\mathrm{AD}$ pathology to tip over the threshold. In the HAAS, the five most important pathologies include microinfarcts, which are clinically silent but are correlated with dementia. ${ }^{53}$
Recent studies have highlighted cerebral arteriolosclerosis to be common in $\mathrm{AD}$ and other dementias. ${ }^{19}$ The arteriolar wall modifications ${ }^{3}$ comprise fibrinoid necrosis (and/or lipohyalinosis), microatheromas, and segmental arterial disorganization (Figure 1). Focal arteriolosclerotic changes characterized by degeneration of vascular myocytes (acellular) with concentric accumulation of extracellular matrix components, such as collagen and fibroblasts, are often evident in small vessels in the deep WM and basal ganglia. ${ }^{43}$ Both cerebral arteriolosclerosis and atherosclerosis are independently associated with dementia and contribute to low scores in most cognitive domains, suggesting that covert vessel pathology is an under-recognized risk for $\mathrm{AD}$ dementia. ${ }^{54}$ Interestingly, the presence of apolipoprotein $\mathrm{E}$ (APOE; ApoE) $\varepsilon 4$ allele or vascular risk factors did not change the association between either of these vascular pathologies and dementia outcome. ${ }^{52}$ There is also likely to be a complex, yet unappreciated, physiological interaction between risk factors associated with metabolic syndrome such as hypertension and inflammation to culminate in the arteriolar pathology. ${ }^{19}$

Arteriolar changes in familial AD do not appear to be vastly different from familial SVD such as those in cerebral autosomal dominant arteriopathy with subcortical infarcts and leukoencephalopathy (CADASIL). ${ }^{55}$ In the PSEN1 Pro117Leu mutation carriers, in addition to attenuation and perivascular spaces in the WM, there is an accelerated process of transformation in arteriolar myocytes characterized by loss of the tunica media, marked fibrous thickening of arteries and arterioles, and double-barreled arterioles that are comparable to, but distinct in some ways, from those in CADASIL. Cerebral capillaries with $A \beta$ deposits also reveal enhanced expression of fibrillar collagen 3 and 4 . Ultrastructural studies indicate the presence of both $A \beta$ and collagen fibers within thickened basement membrane of capillaries. Degenerated-appearing pericytes are also observed with clusters of collagen fibers between lamellae of basement membranes. ${ }^{56}$ In general, these observations are consistent with other pathologic studies of familial AD. ${ }^{44,47,57}$

Patterns of SVD are remarkably similar in neurodegenerative diseases, and the WM is particularly vulnerable irrespective of primary ischemic injury or a proteinopathy. ${ }^{3,58}$ The natural history and staging of SVD suggest that arteriolosclerosis and CAA are the earliest changes. Modifications in perivascular spaces and myelin loss are the next most common lesions. Lacunar or regional infarcts, microinfarcts, and microbleeds occur because of an independent process or in the final phases of SVD (Figure 1). These may result from occlusion by microemobili or microthombi originating form artery-to-artery thromboembolism and emboli from the heart. ${ }^{59}$ Other causes include microaneurysms and repeated parenchymal injury resulting from the disruption of flow due to arteriolar stiffening and tortuosity. The regional progression of vessel changes suggests that CAA proceeds from neocortical to subcortical 
Table 1 Radiological and Pathologic Features of Spectrum of Small Vessel Disease in AD Dementia

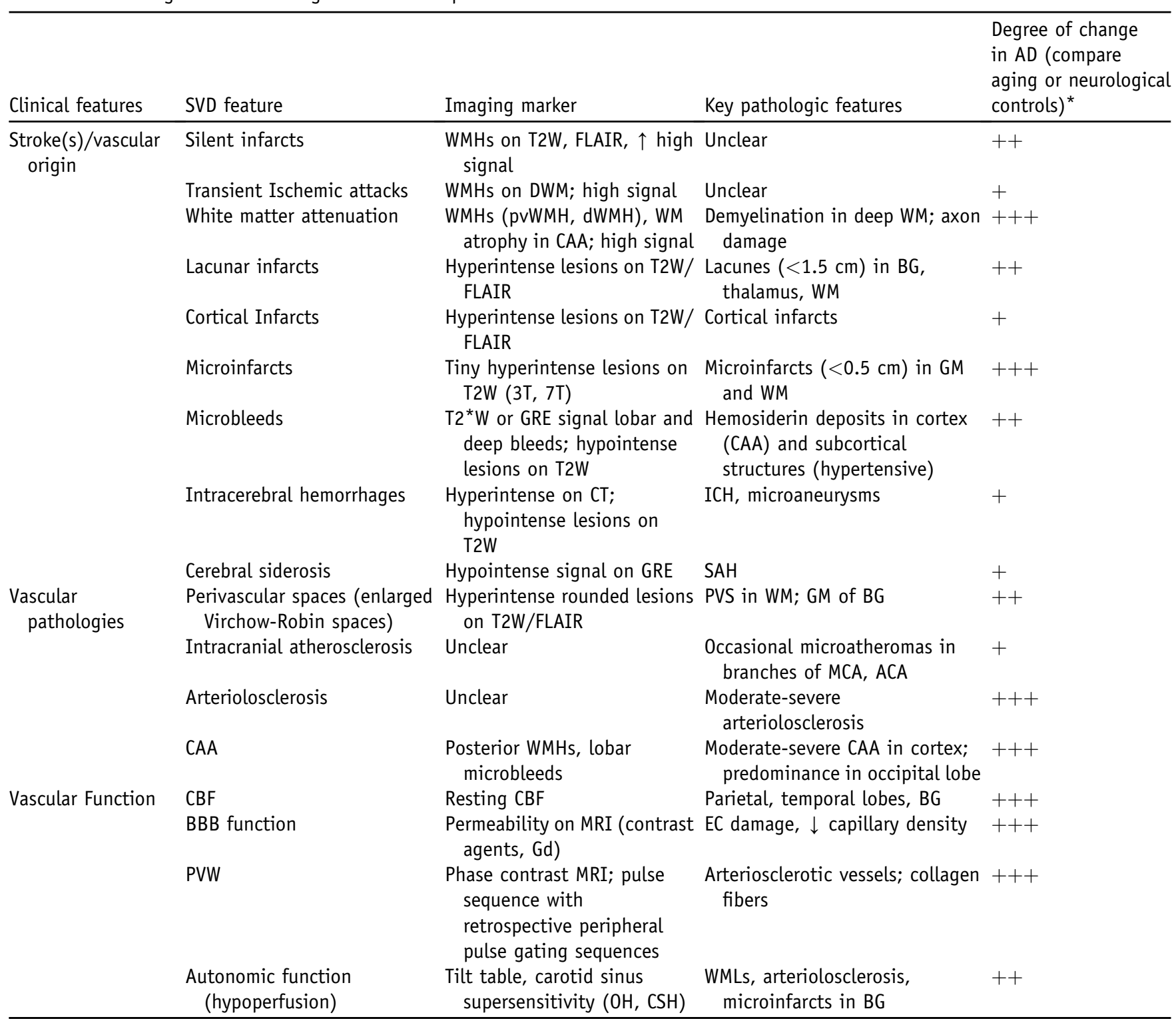

Neuroimaging and pathologic changes involving SVD in AD.

*Changes found in AD type of dementia above and beyond normally aging healthy subjects. Arrow $(\uparrow)$ indicates increase. Scale of change means scores: + , mild (1); ++ moderate (2), severe +++ (3). Microhemorrhages may be caused by leakage by two mechanisms: microaneurysms and rupture of walls due to deposition of fibrillar proteins or iron. ${ }^{28}$

ACA, anterior cerebral artery; AD, Alzheimer disease; BG, basal ganglia; CAA, cerebral amyloid angiopathy; CBF, cerebral blood flow; CSH, carotid sinus hypersensitivity; DWM, deep white matter; dWMH, deep white matter hyperintensities; EC, endothelial cell; FLAIR, fluid attenuated inversion recovery; Gd, gadolinium; GM, grey matter; GRE, gradient echo; ICH, intracerebral hemorrhage; MCA, middle cerebral artery; MRI, magnetic resonance imaging; $0 \mathrm{H}$, orthostatic hypotension; PVS, perivascular space; pvWMH, periventricular white matter hyperintensities; PVW, pulse wave velocity; SAH, subarachnoid hemorrhage; SVD, small vessel disease; WM, white matter; WMH, white matter hyperintensities; WML, white matter lesion.

structures. Although pre-existing hypertensive disease distorts and damages the microvasculature, ${ }^{19}$ cerebral vessels laden with $\mathrm{A} \beta$ aggregates cause arteriosclerotic changes and damage the endothelium. Specific segmental patterns of capillary and arteriolar dysfunction appear to contribute to CAA and AD pathology. ${ }^{42,60}$ Although initiating factors causing CAA microangiopathy may be different, end-stage pathology appears invariably similar, involving replacement of myocytes with collagenous or other nontensile fibrillar material in both sporadic and familial cases. Intracranial arterial dolichoectasia also appears another cause of SVD, although this has not been widely described in AD. Microaneurysms arise in the context of hypertension, at weakened sites in vessel walls. The walls of aneurysms are composed of hyaline connective tissue, damaged myocytes, and elastica interna that may rupture to produce globular hemorrhages. They are transformed into fibrocollagenous balls, evident as complex tortuosities, when they heal due to 


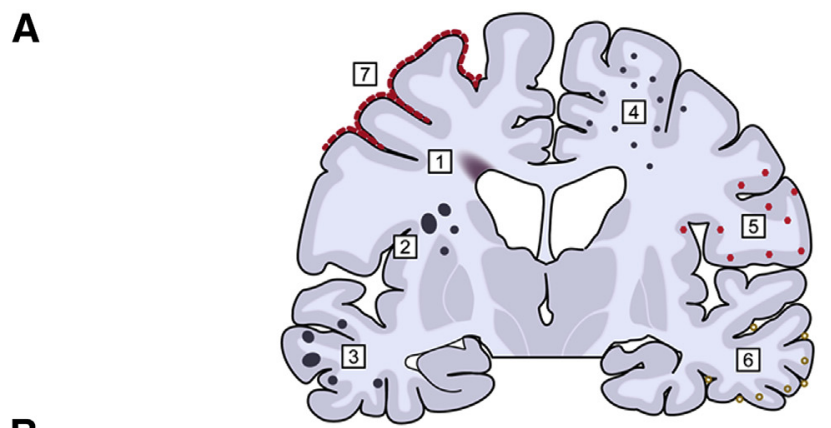

B
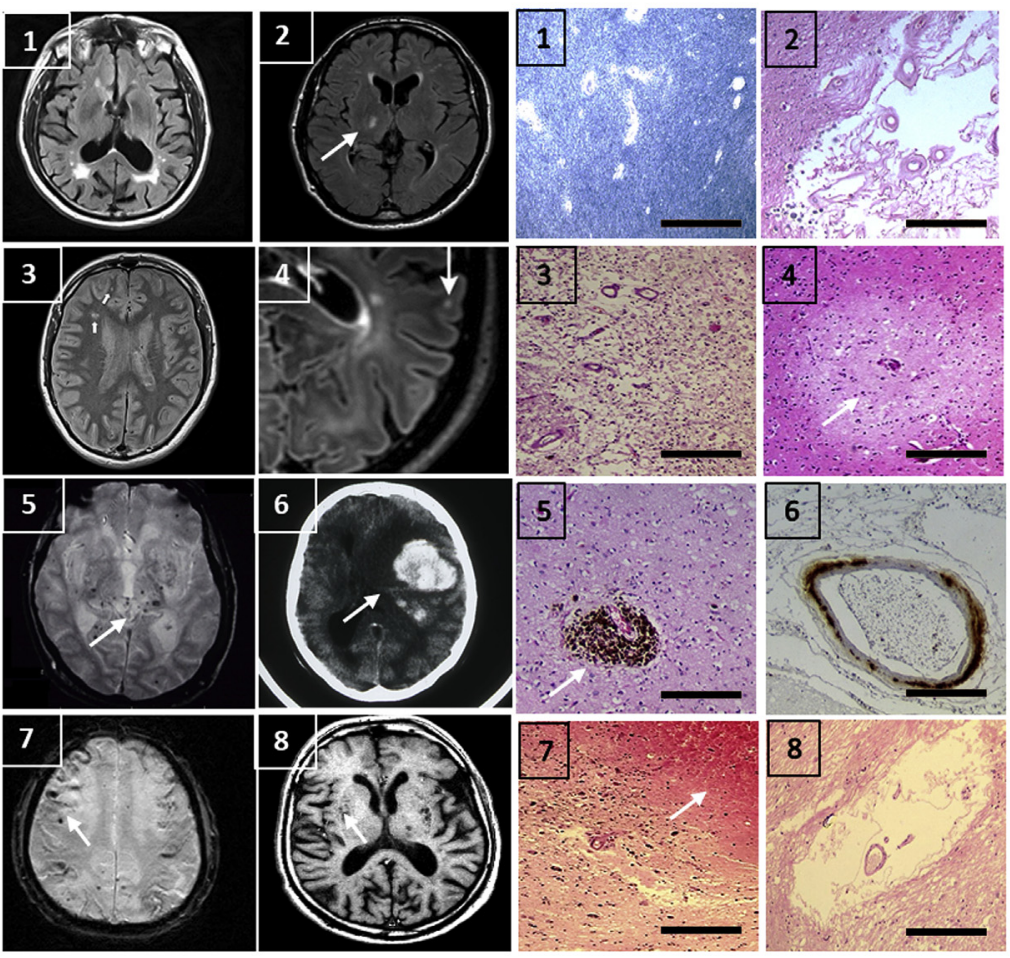

C

\section{\% SVD Lesions}

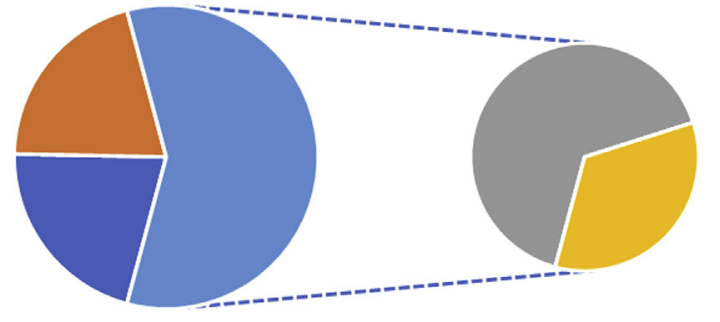

- Small/Lacunar Infarcts

Microinfarcts

- Arteriolosclerosis

$\because \mathrm{CAA}$
Figure 1 A: Schematic of a coronal brain section showing different types of SVD pathologies found in sporadic and familial AD. Numbers in boxes (1 to 7) correspond to the location and type of lesions in $\mathbf{B}$. Location of perivascular spaces is generally in the WM and subcortical structures including the basal ganglia and thalamus (see image 8, axial MR scan, and corresponding histopathological image 8 on right). B: Images 1 to 8 (left) show MR scans in the axial plane with different lesions recognized and quantified in $A D$ patients during life. Images 1 to 8 (right) show microscopic images of equivalent pathologies found in late-onset $A D$ cases. Each of the pathologies has been demonstrated and often quantified in different cohorts consistently indicating greater representation of these pathologies in sporadic as well as familial $A D$ than in aging controls or less common neurodegenerative dementias. ${ }^{3,4}$ These include perivascular and deep WM lesions or attenuation (image 1 , right and left), lacunar infarcts $(<1.5 \mathrm{~cm}$ ) (image 2 , right and left), cortical or WM infarcts (1 to $2 \mathrm{~cm}$ ) (image 3, right and left) in a PSEN1 Glu280Ala, microinfarcts $(<0.5 \mathrm{~cm})$ (image 4 , right and left), lobar or deep microbleeds or hemosiderin (image 5, right and left), CAA or CAA-related ICH (image 6, right and left), superficial siderosis (image 7, right and left), and perivascular spaces (image 8 , right and left). Increased perivascular spacing occurs because of reduction in arterial vascular tone and lack of perivascular solute drainage. ${ }^{35}$ The WM changes ensue due to a chronic hypoxic state and decline in oligodendrocytes. ${ }^{36,37}$ Arrows in panels show the location of key lesion(s). C: Pie chart shows average proportions of SVD pathologies in community-based observational and longitudinal cohort studies. \% SVD lesions involve at least one lacunar infarct, a microinfarct, moderate-to-severe arteriolosclerosis, or CAA. Arteriolosclerosis is sometimes described as arteriosclerosis or total SVD. Perivascular spaces or WM attenuation or WM lesions were not consistently recorded. Microinfarct, unless specified, was considered that seen with the light microscope or to be $<1$ $\mathrm{mm}$ in diameter. ${ }^{38}$ MR fluid attenuated inversion recovery image (image 3, left) from a 57-year-old male subject was kindly provided by and used with permission from Dr. Yakeel T. Quiroz (Departments of Psychiatry and Neurology, Harvard Medical School, Boston, MA). Scale bars $=50 \mu \mathrm{m}(B)$. AD, Alzheimer disease; CAA, cerebral amyloid angiopathy; ICH, intracerebral hemorrhage; $M R$, magnetic resonance; SVD, small vessel disease; WM, white matter. thrombosis and fibrosis. They are most common at the interface between the grey matter and WM in most dementias.

Atherosclerosis coexists with sporadic SVD involving large extracranial vessels and cardioembolic disease. Some cohort studies have reported that atheromas within basal brain vessels are common in AD. ${ }^{4,52,61}$ Small vessel atherosclerosis or microatheromas are occasionally also found within proximal segments of penetrating arteries at junctions of branching and parent arteries, and in parent vessels overlying the branch origin. The pathogenesis of atherosclerosis in small cerebral vessels does not differ substantially from that in extracranial vessels but is characterized by macrophages and nearly complete stenosis. ${ }^{28}$ It is not surprising that subsets of proteins and modules associated with cerebral atherosclerosis were also found in AD brains. ${ }^{62}$ 


\section{Radiologically-Defined SVD in Late-Onset AD}

WMH on T2-weighted magnetic resonance imaging (MRI) have been invariably considered as radiological surrogate markers for SVD (Figure 1). The frequency of WMH or WM lesions increases to $94 \%$ by 80 years of age. The lesions are more common and extensive in patients with cardiovascular risk factors, and increase risk of stroke, dementia, and death. Both periventricular and deep WMH of vascular origin are common in late-onset $\mathrm{AD},{ }^{63}$ and $\mathrm{WMH}$ and $\mathrm{A} \beta$ accumulation worsen cognitive outcomes. ${ }^{64,65} \mathrm{~A}$ recent systematic analysis indicated that extensive WMH burden was associated with higher risk of $\mathrm{AD}$ (HR, 1.5), suggesting that MRI markers of vascular brain injury have major clinical significance and implicate prevention strategies in individuals with covert SVD. ${ }^{5}$ Some frontal periventricular and posterior WMH or WM lesions are present in a large majority of familial cases of $\mathrm{AD}{ }^{66}$ In keeping with the pathology, ${ }^{43} \mathrm{AD}$ subjects also have less subcortical grey matter and WM with greater volumes of whole-brain, periventricular, and deep WM subcortical hyperintensities as well as lacunar lesions. ${ }^{67}$

Diffusion tensor imaging has been used to assess WM microstructural integrity and assess the progression of neurodegeneration in initial stages of disease. ${ }^{68,69}$ Whether spatiotemporal patterns of these WM changes precede dementia symptoms in $\mathrm{AD}$ is uncertain. However, WM microstructural changes and increased water diffusivity in the $\mathrm{WM}$ in $\mathrm{AD}$ appear akin to SVD. Increased free water in normal-appearing $\mathrm{WM}$ in $\mathrm{AD}$ even without overt cerebrovascular disease suggests that mild vascular damage may occur due to microvascular degeneration and neuroinflammation-related BBB permeability. ${ }^{70}$ In addition to $\mathrm{WMH}$, a repertoire of SVD features can be detected by MRI in AD that are routinely demonstrated under the microscope (Figure 1). This includes lacunar infarcts, perivascular spacing, microbleeds, and microinfarcts. Most lacunar infarcts are clinically silent, as are microinfarcts, but both are found in greater numbers in $\mathrm{AD}$ compared with healthy aging subjects. These lesions may gradually disrupt cognitive network, modify global cognitive performance, and cause focal atrophy. Independent of the proteinopathy in $\mathrm{AD}$, ongoing studies with more sensitive 7-T MR scanners and higher resolution modalities using 3-T suggest that microinfarcts and microbleeds ${ }^{71}$ arise from cardiac microemboli, supporting the role of cardiovascular abnormalities in AD. Microbleeds as radiological evidence of SVD have also been detected in familial $\mathrm{AD}$, specifically in patients carrying PSEN1 missense mutations Ala260Gly, Pro284Ser, and Pro355Ser (AlzForum, http://www.alzforum.org/mutations, last accessed January 15, 2021).

Above all, the evidence for the presence of SVD in both sporadic and familial AD is compelling, although the interactions between vascular and neurodegenerative processes may not be understood. In support of the radiological findings and presence of other biomarkers of SVD, collective evidence from the Alzheimer's Disease Neuroimaging Initiative (ADNI) studies suggests that vascular alterations such as cerebrovascular resistance and hypoperfusion precede $\mathrm{A} \beta$ deposition and are predictive of disease progression. ${ }^{72-74}$ Analysis of $>7700$ brain images and 1000 plasma and cerebrospinal fluid (CSF) biomarkers suggests that intrabrain vascular dysregulation is an early pathologic event during disease development. High abnormal levels of specific proteins associated with the integrity of the vascular system have been noted. This strongly implicates the inclusion of covert SVD features in the biomarker model of $\mathrm{AD}$ depicting disease progression. Congruent with this, brain extracellular vesicles were identified with molecular mediators of hypoxia responses and neuroprotection in preclinical $\mathrm{AD}$ and mixed dementias, supporting involvement of a vascular component in the etiology of $\mathrm{AD} .^{75}$

Elderly free of cardiovascular disease including atrial fibrillation have a lower cardiac index or output, which corresponds with lower cerebral blood flow (CBF) in the temporal lobes. $^{76}$ In addition, cardiovascular disease including myocardial infarction in midlife is more associated with lower grey matter perfusion in older age, but not very late in life. ${ }^{29}$ Using advanced dynamic contrastenhanced MRI sequences with high spatial and temporal resolutions, BBB breakdown in the hippocampus was suggested to occur in early stages of $\mathrm{AD}$ prior to laying down of disease pathology. This breach appears worse in individuals with mild cognitive impairment. Both clinical imaging and CSF biomarker studies indicate BBB abnormalities ${ }^{77}$ with reduced CBF occur 10 to 20 years prior to onset of clinical symptoms of $\mathrm{AD} .^{78}$ More recent studies have shown that CSF changes in markers of pericyte injury and BBB damage predict cognitive decline in patients with mild cognitive impairment independently of accumulation of $\mathrm{A} \beta$ or hyperphosphorylated tau. ${ }^{77,79}$ Thus, focal vascular dysfunction appears in early phases of $\mathrm{AD}$ perhaps concomitant with initial $A \beta$ accrual. Observations from sporadic disease are consistent with earlier findings in the Colombian PSEN1 Glu280Ala mutation carriers; regional cerebral perfusion abnormalities detected on single-photon emission tomography occur before development of clinical symptoms. ${ }^{48}$ AD patients also demonstrate decreased perfusion in the posterior parietal and superior frontal cortex.$^{80}$ In another study on familial AD, early CBF changes particularly in the lenticulostriate arterial territories were identified in asymptomatic and mildly symptomatic subjects. ${ }^{81}$

The endothelium of cerebral vessels and capillaries represents a vulnerable interface, which may be chronically activated in SVD. ${ }^{9,28,35}$ It has been proposed that in SVD, capillary flow patterns are disrupted to retard oxygen extraction and cause SVD-like pathology and lead to neurodegeneration. ${ }^{82}$ However, not only hemodynamic events, but also arteriolar wall disintegration resulting from arterial 
Table 2 Molecular Pathology of the Microcirculation and BBB in Late-Onset AD

\begin{tabular}{|c|c|c|}
\hline Cellular feature & Morphological changes & Biochemical markers \\
\hline \multirow[t]{2}{*}{$\begin{array}{l}\text { Cerebral endothelium loss of glucose } \\
\text { transporter, } \mathrm{Na}+/ \mathrm{K}+\text { ATPase }\end{array}$} & $\begin{array}{l}\text { Loss of cytoplasm and endoplasmic } \\
\text { reticulum. Increased pinocytosis. }\end{array}$ & $\downarrow$ GLUT1, Na+/K+ ATPase, CD31, CD34 \\
\hline & $\begin{array}{l}\text { Endothelial membranes/microvascular } \\
\text { endfeet }\end{array}$ & $\begin{array}{l}\downarrow \text { Alkaline phosphatase, } \gamma \text {-GGT, } \\
\text { cholinesterases }\end{array}$ \\
\hline Vascular basement membrane & Thickening of the ECM, collagen fibers & $\begin{array}{l}\uparrow \mathrm{COL} \text {, perlecans, fibrinogen, matrix } \\
\text { metalloproteinases }\end{array}$ \\
\hline \multirow[t]{2}{*}{ Perivascular cells } & Increased astrocytic feet & $\uparrow$ GFAP reactivity \\
\hline & Pericytes: cell numbers and coverage & $\begin{array}{l}\uparrow \text { CSF sPDGFR } \beta 1 ; \uparrow \text { cortex PDGFR } \beta 1 \text { cortex; } \\
\downarrow \text { WM PDGFR } \beta 1 ; \uparrow \text { perivascular } \\
\text { macrophage markers, CD68, TREM2 }\end{array}$ \\
\hline
\end{tabular}

Summary of observations derived from several previous studies. ${ }^{9,28,35}$ Arrows indicate decreases $(\downarrow)$ or increases $(\uparrow)$.

$A \beta$, amyloid $\beta$ protein; $A D$, Alzheimer disease; AlkP, alkaline phosphatase; BBB, blood-brain barrier; $C D$, clusters of differentiation markers; $C D 31, C D 34$ cluster of differentiation markers 31 and 34 for endothelium; CD68, cluster of differentiation marker 68 for microglia; COL, collagens; CSF, cerebrospinal fluid; EC, endothelial cell; ECM, extracellular matrix; eNOS, endothelial nitric oxide synthase; GFAP, glial fibrillary acid protein; GGT, $\gamma$-glutamyl transpeptidase; GLUT1, glucose transporter 1 ; HIF-1 $\alpha$, hypoxia inducible factor $1 \alpha$; NV, neurovascular; PDGFR $\beta$, platelet-derived growth factor receptor $\beta$; PVS, perivascular space; SMC, smooth muscle cell; TREM2, triggering receptor expressed on myeloid cells 2; VEGF, vascular endothelial growth factor; WM, white matter.

stiffening, may weaken the BBB and cause chronic leakage of fluid and macromolecules (Table 2 and Figure 2). In time, this may induce an inflammatory response with increased traffic in neutrophils and lymphocytes or perivascular macrophages. In older cases, age-related decline in BBB restoration mechanisms via astrocytic response may also promote microhemorrhages in the form of perivascular hemosiderin (Figure 2). Even though so far, there is no conclusive evidence of $\mathrm{BBB}$ damage in familial $\mathrm{AD}$ independent of CAA, early or non-amyloidogenic BBB breakdown has been identified in several $A D$ murine models involving amyloid precursor protein (APP), PSEN1, tau, and $-A P O E$ mutations. These findings include loss of endothelial tight junctions, basement membrane degeneration. and pericytes loss. Of particular relevance is the mice lacking PSEN1 presenting with abnormal vessel development. ${ }^{83}$ This effect can be attributed to the role of $\gamma$-secretase in the cleavage and activation of Notch3, a key player in angiogenesis.

\section{WM Pathology and SVD in AD}

Cerebral WM rarefaction or attenuation is a frequent structural change in AD (Figure 2). Periventricular WM lesions are similar to those in Binswanger's disease in up to $60 \%$ of $\mathrm{AD} .{ }^{84}$ Post-mortem studies showed that patterns of loss of myelin in $\mathrm{AD}$ are similar to those in vascular dementia. ${ }^{37}$ Axonal degeneration and gliosis in the deep $\mathrm{WM}$ are also described to be common in AD. Similarly, other components of the gliovascular unit including capillaries undergo degeneration and dilation in the WM in AD. ${ }^{58,85}$ Pathologic correlates of WMH when SVD is obvious suggest demyelination, axonal abnormalities, clasmatodendrosis, microglial activation, hemosiderin deposits, arteriolosclerosis, pericyte cell loss, and BBB dysfunction secondary to degrees of vascular brain injury. ${ }^{86}$ In support of these morphological findings, Wong et $\mathrm{al}^{87}$ provided in vivo evidence to suggest the integrity of the $\mathrm{BBB}$ is compromised in relation to cerebral hypoperfusion in the WM. They reported that lower CBF was correlated with higher leakage measures in the perilesional zones, which became stronger in the proximity of WMH. However, such WM alterations cannot be fully accounted for by degenerative processes secondary to grey matter damage, ${ }^{68,84}$ but may stem from vascular amyloid deposition, microvascular damage, and lack of solute drainage. ${ }^{88}$

Diffusion tensor imaging studies in mutation carriers in familial $\mathrm{AD}$ indicate changes in the cerebral WM occur years before symptom onset. ${ }^{89}$ The mean diffusivity within the posterior parietal and medial frontal WM in mutation carriers was found to be stronger than in noncarriers. Higher mean diffusivity in fiber tracts was associated with lower grey matter volume in projection zones. These results suggest that regionally selective WM damage occurs considerably before the onset of disease that is associated with 

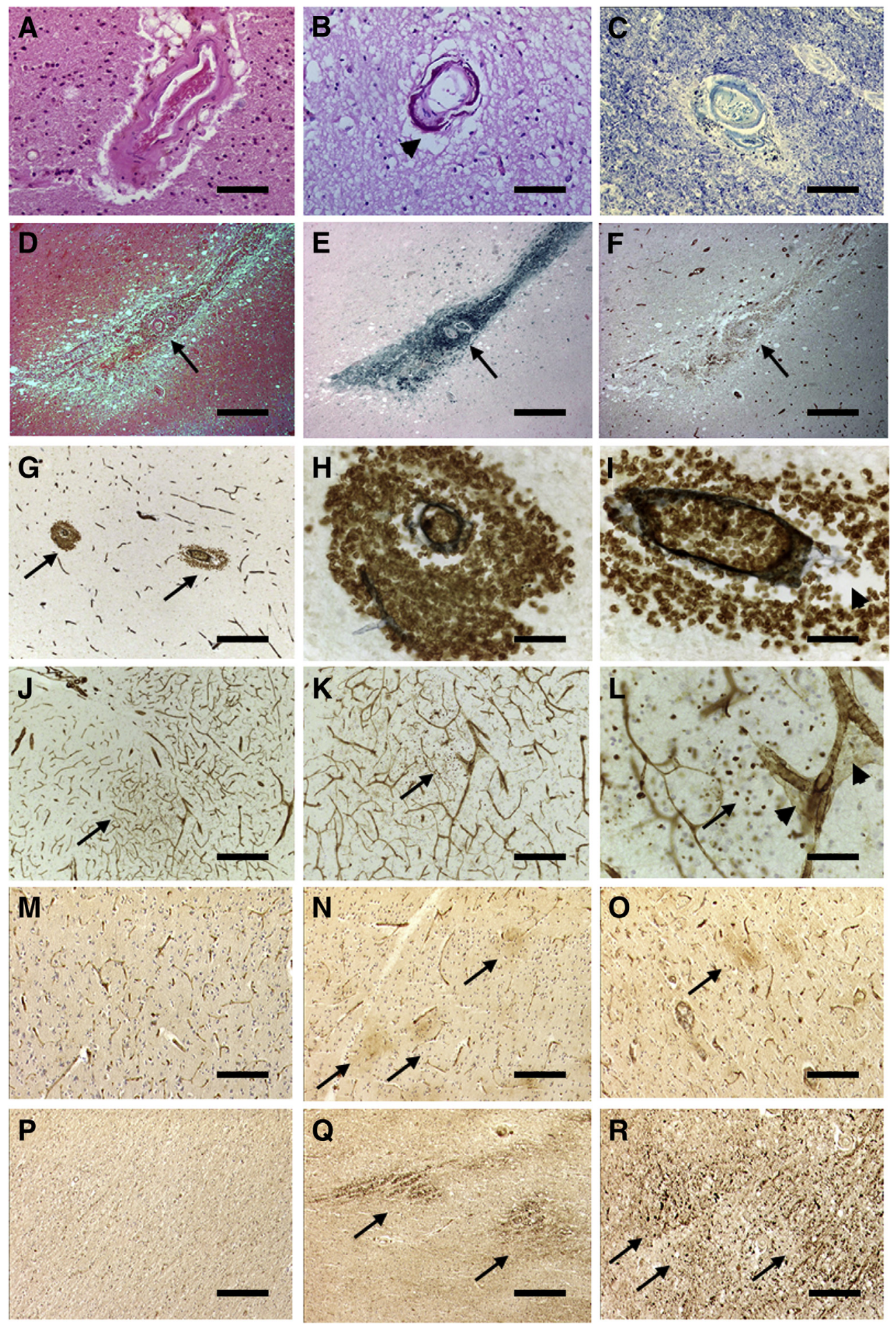

Figure 2 Cerebrovascular pathology in subcortical WM in AD. A-C: Severe arteriolar hyalinization (A), calcification in basal ganglia (B), and moderately hyalinized vessel in rarefied WM (C). D-F: Periarteriolar microhemorrhage (arrows) in temporal WM in a subject with CAA. Serial sections stained with hematoxylin and eosin (D), Perl's stain for iron (E), and GLUT1 antibody (brown) (F). G-I: Double immunohistochemistry (brown $=$ GLUT1, black = COL4) shows leakage sites of GLUT1-positive erythrocytes perivascular to arterioles in the WM of an AD case. G: Arrows indicate perivascular infiltrates, shown at higher magnification in $\mathbf{H}$ and $\mathbf{I}$. $\mathbf{J}-\mathbf{L}$ : Double immunohistochemistry (brown $=$ GLUT1, black = COL4) shows sites of infiltration of GLUT1-positive erythrocytes around capillaries and arterioles (arrows), some showing increased perivascular spaces (arrowheads). Comparison of images in panels D-F and G-I demonstrates differences in chronic and acute leakage from blood. $\mathbf{M - 0}$ : ICAM1 IR in the WM of aging control (M), AD (N), and VaD (0) subjects. Increased IR in vessel walls and diffuse deposits is shown (arrows). Fibrinogen showed similar IR. P-R: APP IR in the WM of aging control (P), AD (Q), and VaD (R) subjects. Diffuse APP IR shows sites of damage (arrows). B, F, and I: Note the frequent perivascular spaces found in the WM in $A D$ (arrowheads). Scale bars $=50 \mu \mathrm{m}$. AD, Alzheimer disease; APP, amyloid precursor protein; CAA, cerebral amyloid angiopathy; COL, collagen 4; GLUT1, glucose transporter 1; ICAM1, intracellular adhesion molecule 1; IR, immunoreactivity; SVD, small vessel disease; VaD, vascular dementia; WM, white matter. 
Table 3 Familial AD Causative Mutations for CAA

\begin{tabular}{|c|c|c|c|c|}
\hline Gene & Mutation* & $\mathrm{CAA}^{\dagger}$ & Notes $^{\ddagger}$ & References $^{\S}$ \\
\hline \multirow[t]{9}{*}{$A P P$} & LysMet670/671AsnLeu & Yes & Mouse model, CAA at $12-19$ months & 106 \\
\hline & Ala673 Val & Yes & & 107 \\
\hline & Asp678His & Yes & Also present with cerebral microvasculopathy (23931937) & 108 \\
\hline & Ala692Gly & Yes & & 109 \\
\hline & Glu693Gly & Yes & Mouse model shows no CAA & 106 \\
\hline & Glu693Lys & Yes & & 110 \\
\hline & Ala713Thr & Yes & WM changes, cerebral microangiopathy and CAA ${ }^{\|}$ & 113,154 \\
\hline & Thr714Ile & Yes & $\begin{array}{l}\text { Transgenic APP695 mouse harboring Lys670Asn, Met671Leu, and } \\
\text { Thr714Ile, develops CAA }\end{array}$ & 114 \\
\hline & Ile716Phe & Yes & & 106 \\
\hline \multirow[t]{31}{*}{ PSEN1 } & Ile83_MetM84del & Yes & 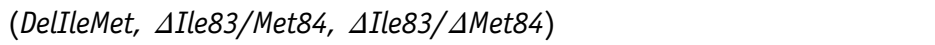 & 119 \\
\hline & Met84Thr & Yes & & 120 \\
\hline & Val89Leu $(G>T)$ & Yes & & 121 \\
\hline & Leu113_Ile114insThr & Yes & (Intron4, p.113+1delGly, splice5, InsThrAlaCys) & 122 \\
\hline & Leu113Glns & Yes & & 123 \\
\hline & Thr116Asn & Yes & & 124 \\
\hline & Pro117Leu & Yes & & 56 \\
\hline & Glu120Gly & Yes & & 125 \\
\hline & Asn135Tyr & Yes & & 126 \\
\hline & Met139Val & Yes & & 127 \\
\hline & Ile143Met & Yes & CAA prominent in meningeal vessels & 47 \\
\hline & Gly266Ser & Yes & & 136 \\
\hline & Pro267Ala & Yes & & 137 \\
\hline & Leu268Pro & Yes & & 138 \\
\hline & Arg269His & Yes & & 139 \\
\hline & Leu271Val & Yes & & 140 \\
\hline & Val272Ala & Yes & & 141 \\
\hline & Arg278Ile & Yes & & 127 \\
\hline & Glu280Ala & Yes & Paisa mutation & 142 \\
\hline & GluE280Gly & Yes & & 143 \\
\hline & Leu282Val & Yes & & 144 \\
\hline & Pro284Leu & Yes & & 145 \\
\hline & Leu286Pro & Yes & & 138 \\
\hline & Ser290Cys & Yes & Thr291_Ser319del ( $\Delta$ Ala9, $\Delta 9)$ & 146 \\
\hline & Gly378Glu & Yes & & 123 \\
\hline & Leu392Val & Yes & & 145 \\
\hline & Asn405Ser & Yes & & 147 \\
\hline & Gly417Ser & Yes & & 148 \\
\hline & Ala431 Val & Yes & & 145 \\
\hline & Thr440del & Yes & & 149 \\
\hline & & & & e continues) \\
\hline
\end{tabular}


Table 3 (continued)

\begin{tabular}{lllll}
\hline Gene & Mutation* & CAA $^{\dagger}$ & Notes $^{\ddagger}$ & References $^{\S}$ \\
\hline PSEN2 & Aal85Val & Yes & & 150 \\
& Lys115Glufs & Yes & & 151 \\
& Asn141Ile & Yes & Volga German mutation & 152 \\
& Leu221Thr & Yes & & 153 \\
\hline
\end{tabular}

*Genotypes of different mutations per original references derived from the Alzforum Database ( $h$ ttp://www.alzforum.org/mutations, last accessed January 15, 2021).

'Presence of variable degrees of CAA predominantly in cortical regions.

${ }^{\ddagger}$ Presence or absence of CAA in various transgenic mouse models and features noted in case reports.

SReferences include citations of four abstracts.

TMagnetic resonance imaging positive for microbleeds suggests likely CAA (compare Figure 1B, images 5 and 6).

"First case in Argentina with APP Ala171Thr mutation showing marked vascular pathology. ${ }^{154}$

$\mathrm{AD}$, Alzheimer disease; APP, amyloid precursor protein; CAA, cerebral amyloid angiopathy; PSEN1, presenilin 1; PSEN2, presenilin 2; WM, white matter.

primary $\mathrm{AD}$ pathology and microglia activation rather than any overt vascular disease. WM changes in neurodegenerative diseases could reflect pathologic processes other than those involved in SVD, that is, that nonvascular damage could increase fluid motion in discrete areas of the WM to result in hyperintense signals. ${ }^{90}$ However, early changes in WM cannot all be explained by neurodegenerative pathology because there would not be sufficient burdens of neurodegenerative pathology at early stages. ${ }^{1}$ Is it possible then, that the presence of low perfusion or disturbed arterial pulsation within the deeper layers of the WM disrupts flow in the long perforating arteries to cause a chronic hypoxic state and damage the deep WM?

Similar to indications of BBB damage, there is still no human pathologic evidence of WM damage independent of A $\beta$ pathology (Table 1 and Figure 2). However, alterations in myelin morphology and oligodendrocyte differentiation have been observed early in APP/PSEN1 mice. ${ }^{91}$ Astrocytic clasmatodendrosis has shown to be a pathologic correlate of WM damage. ${ }^{85}$ Accordingly, the authors have observed this feature in the WM of PSEN1 Glu280Ala cases (D. Sepulveda-Falla, R.N. Kalaria, unpublished data).

\section{Consequences of Chronic Vascular Disease}

Besides age, hypertension and diabetes mellitus are among the strong risk factors for SVD. Whereas it is not fully understood how diabetes might lead to SVD,${ }^{92}$ the deleterious effects of increased blood pressure are mediated by structural changes in smaller arteries leading to arteriolosclerosis with two main consequences. First, the progressive segmental loss of myocytes with replacement by collagen fibers reduces vessel wall tone or elasticity in response to variations in blood pressure and loss of autoregulation through disruption of the perivascular nerve plexii. Second, the persistent high pulse pressure leads to focal disruption of capillaries, particularly in the deeper structures. This causes edema and BBB breach with chronic leakage of fluid and macromolecules (Figure 2) as well as incidental infarction, particularly in subcortical structures.
Aging-associated central arterial stiffness may increase SVD features with consequences on progression in the AD continuum. For example, aortic stiffening conveyed by higher pulse wave velocity, and therefore higher pulsatility, was associated with lower CBF particularly in the temporal lobes although cerebrovascular reactivity was preserved in $A P O E \& 4$ allele carriers with mild cognitive impairment. ${ }^{93}$ Consistent with this, higher systolic blood pressure and pulse pressure, ${ }^{94}$ or diastolic blood pressure ${ }^{95}$ attributable to arterial stiffness, were related to greater cerebral retention of Pittsburgh Compound-B $(\mathrm{PiB})$ in presymptomatic and $\mathrm{AD}$ patients. Arterial stiffness, or the surrogate marker pulse wave velocity, and mean arterial pressure were also highest in individuals with both high $\mathrm{PiB}$ retention and $\mathrm{WMH}$ (double hit), promoting the development of $\mathrm{AD} .^{96,97}$ Although resting CBF may not be affected, higher pulsatility index likely promotes larger WMH volumes and increases perivascular spaces in subcortical structures. ${ }^{98}$ It is conceivable that early in the presymptomatic stage prior to the manifestation of disease phenotype, vascular reactivity is compromised due to covert changes in vessel walls whether they are CAA or AD mutation carriers. ${ }^{99}$

Rodent models of $A \beta$ amyloidosis including those exhibiting CAA have demonstrated impairment in different features of cerebrovascular function including $\mathrm{CBF}$, functional hyperemia, and cerebral autoregulation. ${ }^{100}$ Although higher cerebrovascular resistance and altered transfer of $\mathrm{CBF}$ to cortical oxygenation in $\mathrm{AD}$ suggests that the microcirculation and properties of the microvasculature are changed, ${ }^{101}$ all functional measures are not consistently replicated in AD. For example, it is controversial whether autoregulation in $\mathrm{AD}$ is altered per se to reflect in SVDrelated cerebral perfusion. In an earlier study, Zazulia et $\mathrm{al}^{102}$ reported there was absence of significant change in $\mathrm{CBF}$ with a 10 to $15 \mathrm{~mm} \mathrm{Hg}$ reduction in mean arterial pressure within the normal autoregulatory range, suggesting that there was no generalized or local defect of autoregulation. However, using a linear mixed model, a recent study $^{103}$ demonstrated that the efficacy of cerebral autoregulation, assessed during stepwise changes in arterial pressure, was reduced in individuals with amnestic mild 
cognitive impairment, which is a prodromal stage of $\mathrm{AD}$. Various limitations including cohort sizes, coexisting factors, imaging techniques, variability in disease progression and study power can be attributed to inconsistent findings.

\section{SVD and CAA in Sporadic and Familial AD}

For more than 100 years, cerebral congophilic angiopathy, or now widely described as CAA, has been identified as a pathologic hallmark of brain disease ${ }^{104} \mathrm{CAA}$ was originally identified to be associated with wall thickening of small and medium-sized vessels together with the occurrence of cerebral microbleeds. Vessel wall thickening characteristically showed accumulation of eosinophilic material, Congo Red positive, identifying it as amyloid. The most common type of CAA is $A \beta$ angiopathy, which is reported to be as high as $90 \%$ in $\mathrm{AD} .{ }^{105}$ The majority of pathologically verified familial AD subjects exhibit CAA. ${ }^{47,56,106-153}$ The first case in Argentina with marked vascular pathology including CAA carried the APP Ala171Thr mutation. ${ }^{154}$ Specifically, at least 16 mutations in the APP and PSEN1 genes are outright known for CAA in the clinical phenotype (Table 3 ). However, of 68 mutations identified in $A P P, 15$ of them present with CAA. APP mutations are localized between amino acids 670 to 694 and 713 to 717 . The first cluster corresponds to $\alpha$ - and $\beta$-secretase cleavage sites and the second cluster to $\gamma$-secretase cleavage sites, indicating a direct role of abnormal $A \beta$ peptide(s) generation and their accumulation in cerebral vessels. Several murine AD models developed from these APP mutations have indicated CAA as well and have favored research in AD vascular pathology. So far, more than 320 PSEN1 mutations have been identified. Accordingly, 37 PSEN1 missense mutations are associated with the presence of mild-to-severe CAA (Table 3). These mutations are evenly distributed alongside the PSEN1 gene sequence. However, PSEN1 mutations below codon 200 have been characterized as having milder CAA pathology, whereas PSEN1 mutations above codon 200 characteristically show severe CAA. Finally, while 64 mutations for PSEN2 have been identified, at least $4 \mathrm{mu}$ tations have been associated with the presence of CAA (Table 3). It has been suggested that the composition of $A \beta$ aggregates differs between parenchymal deposits and those found in CAA-affected vessels. Parenchymal deposits are typically composed of longer $A \beta$ peptides, often with additional posttranslational modifications. CAA deposits, on the other hand, show shorter forms of A $\beta$ peptides. ${ }^{155}$ Mutations in APP, PSEN1, and PSEN2 genes modify size and biochemical profiles of $\mathrm{A} \beta$ peptides generated from $A P P$. The authors have shown that familial AD cases also show a distinctive $A \beta$ peptide signature in CAA deposits when compared with those from sporadic AD cases. ${ }^{142}$

In sporadic $\mathrm{AD}, \mathrm{CAA}$ is more common in individuals with infarction and hemorrhages, and is also recognized as an independent factor for severe cognitive impairment and dementia. SVD pathology in CAA is characterized by progressive segmental arteriolosclerosis involving the medialadventitial layers of intracranial arteries. Of the two types of CAA, Type I is associated with capillaries implicating focal BBB damage. Pathologic studies have shown variable patterns of CAA between early-onset and late-onset AD; Type I CAA is more common and more severe in APP duplication and missense mutations and in Down's syndrome compared with those in sporadic early- and late-onset $\mathrm{AD}{ }^{44}$ That CAA plays a role in the pathogenesis of microvascular lesions is important, ${ }^{40,156}$ but it is not the only factor, implying that even in familial $\mathrm{AD}$, microvessels may undergo age-related changes prior to the appearance of CAA and independent of $A \beta$ accumulation. ${ }^{88}$ For example, cerebral hypoperfusion associated with WM damage accelerates CAA and promotes cortical microinfarcts. ${ }^{157}$

In early-onset autosomal-dominantly inherited $\mathrm{AD}$ patients, ischemic WM changes can be detected at least 2 decades before the development of dementia. The Dominantly Inherited Alzheimer Network (DIAN) study indicated that mutation carriers had greater total $\mathrm{WMH}$ volumes, which appeared to increase approximately 6 years prior to expected symptom onset. ${ }^{46}$ Given the propensity for a posterior distribution of $\mathrm{WMH}, \mathrm{CAA}$, which tends to be more prominent in the occipital lobe, was thought to be one of the mediating factors. These findings suggest that $\mathrm{WMH}$ are an essential feature of $\mathrm{AD}$ and should be incorporated into the biomarker model and a potential therapeutic target. $^{46,158}$

Besides posterior dominant $\mathrm{WMH}$, the radiological features of CAA include lobar microbleeds, dilated perivascular spaces, and multiple areas of superficial siderosis (Figure 1). Mutation carriers are more likely to have cerebral microbleeds than noncarriers, and patients with microbleeds have higher WMH volumes. Although there is some codependency between WMH and microbleeds, these observations highlight that $\mathrm{WMH}$ represents a core feature of $\mathrm{AD}$ independent of vascular forms of $A \beta{ }^{158}$ In another imaging study, the peak skeletonized mean diffusivity, a measure of cerebral WM microstructural disruption as a simple marker of diffuse global WM heterogeneity, was increased in CAA suggesting a role for WM disruption in causing cognitive impairment in CAA. ${ }^{159}$

\section{Conclusions and Future Directions}

There is a wealth of evidence from neuroimaging and pathologic studies demonstrating that various features of cerebral SVD are inherent to the AD continuum. The presence of greater burdens of SVD pathology in normal aging are evident, not only in late-onset $\mathrm{AD}$, but also in mutation carriers with familial AD. Thus, vascular brain injury and consequent tissue changes in both grey matter 


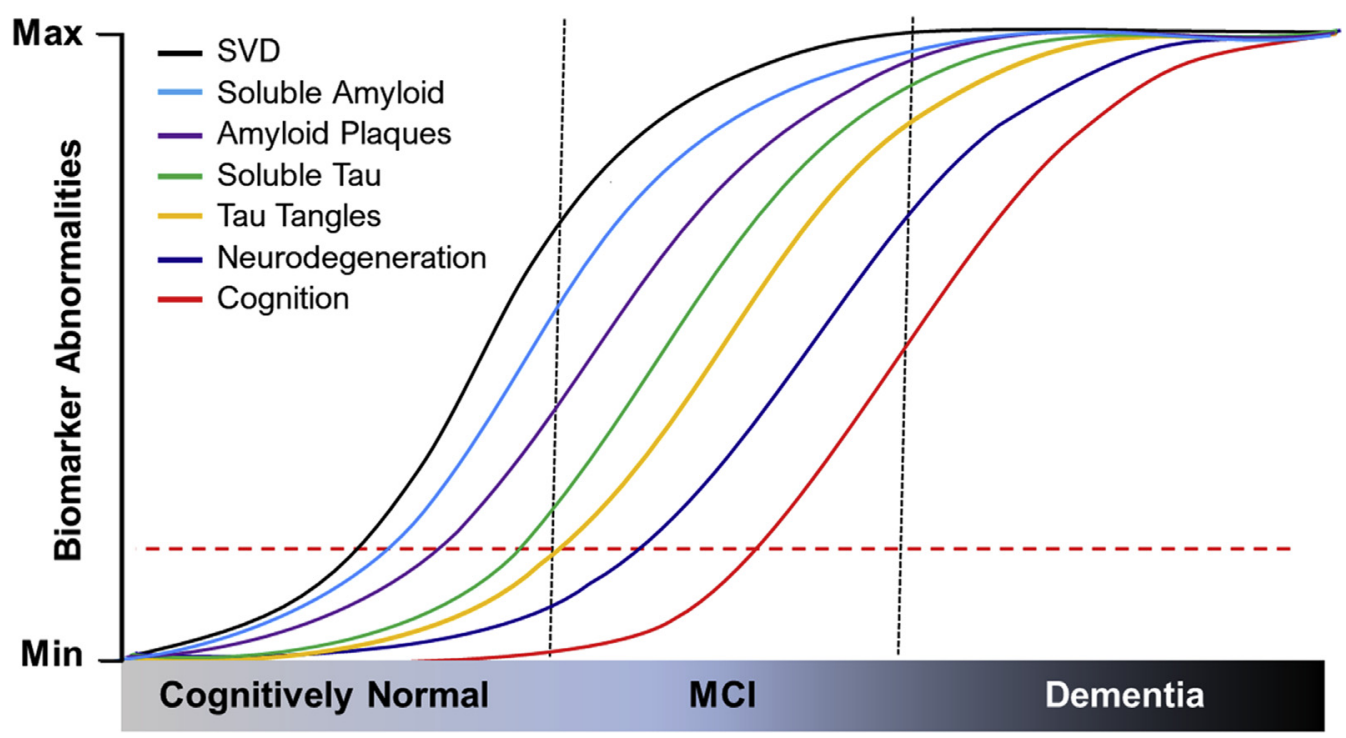

Figure 3 Proposed modification of risk factors and biomarkers of AD in older age. Early changes include vascular disease factors associated with SVD in the progression of $A D$. SVD incorporates covert vascular brain injury including arteriolosclerosis in the early phase that may alter cerebral perfusion to cause WM changes and lead to the recognized biomarkers of AD. Fluctuations in CBF, blood pressure variability, perfusion pressure, PWV, and BBB damage may contribute to prodromal stages in the AD continuum. Vascular factors increase conversion of mild cognitive impairment (MCI) to dementia in the form of frank or clinical AD. These changes also promote changes in CSF and brain $A \beta$ and tau pathophysiology. The $y$ axis represents increasing severity or accumulation of the biomarkers. The horizontal dashed line represents lower threshold changes in markers with minimal impact on clinical symptoms. Neurodegeneration is depicted as a late phase, but it is likely that tissue atrophy occurs concomitantly or as a consequence of SVD or small infarct pathology. ${ }^{28} A \beta$, amyloid $\beta$ protein; $A D$, Alzheimer disease; BBB, blood-brain barrier; CBF, cerebral blood flow; CSF, cerebrospinal fluid; Max, maximum; Min, minimum; PVW, pulse wave velocity; SVD, small vessel disease; WM, white matter.

and WM, particularly in the latter, are the norm rather than the exception. It is further apparent that vascular lesions or SVD modify the progression of disease and increase the odds of dementia (Figure 3). Hypertension-induced arteriosclerotic disease is an important index in $\mathrm{AD}$ as is CAA, which is irrefutably conditional to age-related changes in the cerebral intracranial vasculature. It is thought that vascular brain injury occurs concomitantly with neurodegenerative changes and that these are parallel processes without much mechanistic interaction between them. The fallacy of this argument is that in many studies, vascular brain injury used as a surrogate for SVD is assessed by overt lesions, such as infarcts, ${ }^{28}$ evident both radiologically and pathologically. However, it is more likely that clinically silent lesions or covert changes characteristic of SVD contribute to precipitate $\mathrm{AD}$ type of pathology over long periods of time (Figure 3). Robust proof of this and of vascular risk factors including history of hypertension increasing the burden of $A \beta$ or neurofibrillary pathology are generally lacking. It is plausible that some of the evidence is confounded by selection bias of participants whose vascular risk factors are well-controlled, and markers of SVD such as WMH may not be evident in those at risk. ${ }^{160}$ However, such evidence can be derived from large, comprehensive, prospectively followed longitudinal studies where SVD features including indices assessing BBB damage ${ }^{77}$ are carefully monitored in both individuals at risk and those in the early stages of clinical disease. Evidence of early SVD and WM damage in familial $\mathrm{AD}$ reinforces the certainty of $\mathrm{AD}$ as a multifactorial disorder. From this perspective, it is conceivable that the presence of SVD is either part of the pathologic processes that lead to AD, or that in some patients, SVD coexists with some other possible $\mathrm{AD}$ trigger, lowering the threshold for cognitive dysfunction and eventual dementia. It is probable that other cellular effects of familial $A D$ mutations independent of $A \beta$ deposition also contribute to early SVD in familial AD cases (Figure 3). In the absence of any strong support for therapeutic approaches that lower $A \beta$ deposition or reduce neurofibrillary pathology, it is timely to strongly implement therapeutic and preventative measures that improve or retain functional properties of cerebral small vessels in the context of $\mathrm{AD}$ pathologies including CAA.

\section{Acknowledgments}

We thank Drs. Yumi Yamamoto and Yoshiki Hase for their help with some images in Figures 1 and 2.

\section{Author Contributions}

Both authors critically revised the manuscript for important intellectual content and approved the final version of the manuscript for submission. 


\section{References}

1. Jack CR Jr, Bennett DA, Blennow K, Carrillo MC, Dunn B, Haeberlein SB, Holtzman DM, Jagust W, Jessen F, Karlawish J, Liu E, Molinuevo JL, Montine T, Phelps C, Rankin KP, Rowe CC, Scheltens P, Siemers E, Snyder HM, Sperling R; Contributors: NIAAA Research Framework: toward a biological definition of Alzheimer's disease. Alzheimers Dement 2018, 14:535-562

2. Neuropathology Group of the Medical Research Council Cognitive Function and Aging Study (MRC CFAS): Pathological correlates of late-onset dementia in a multicentre, community-based population in England and Wales. Lancet 2001, 357:169-175

3. Deramecourt V, Slade JY, Oakley AE, Perry RH, Ince PG, Maurage CA, Kalaria RN: Staging and natural history of cerebrovascular pathology in dementia. Neurology 2012, 78:1043-1050

4. Toledo JB, Arnold SE, Raible K, Brettschneider J, Xie SX, Grossman M, Monsell SE, Kukull WA, Trojanowski JQ: Contribution of cerebrovascular disease in autopsy confirmed neurodegenerative disease cases in the National Alzheimer's Coordinating Centre. Brain 2013, 136:2697-2706

5. Debette S, Schilling S, Duperron MG, Larsson SC, Markus HS: Clinical significance of magnetic resonance imaging markers of vascular brain injury: a systematic review and meta-analysis. JAMA Neurol 2019, 76:81-94

6. Wang R, Laveskog A, Laukka EJ, Kalpouzos G, Backman L, Fratiglioni L, Qiu C: MRI load of cerebral microvascular lesions and neurodegeneration, cognitive decline, and dementia. Neurology 2018, 91:e1487-e1497

7. DeCarli C, Villeneuve S, Maillard P, Harvey D, Singh B, Carmichael O, Fletcher E, Olichney J, Farias S, Jagust W, Reed B, Mungas D: Vascular burden score impacts cognition independent of amyloid PET and MRI measures of Alzheimer's disease and vascular brain injury. J Alzheimers Dis 2019, 68:187-196

8. Snowdon DA, Greiner LH, Mortimer JA, Riley KP, Greiner PA, Markesbery WR: Brain infarction and the clinical expression of Alzheimer disease. The Nun Study. JAMA 1997, 277:813-817

9. Sweeney MD, Montagne A, Sagare AP, Nation DA, Schneider LS, Chui HC, et al: Vascular dysfunction-the disregarded partner of Alzheimer's disease. Alzheimers Dement 2019, 15:158-167

10. Veitch DP, Weiner MW, Aisen PS, Beckett LA, Cairns NJ, Green RC, Harvey D, Jack CR Jr, Jagust W, Morris JC, Petersen RC, Saykin AJ, Shaw LM, Toga AW, Trojanowski JQ, Alzheimer's Disease Neuroimaging Initiative: Understanding disease progression and improving Alzheimer's disease clinical trials: recent highlights from the Alzheimer's Disease Neuroimaging Initiative. Alzheimers Dement 2019, 15:106-152

11. Akinyemi RO, Mukaetova-Ladinska EB, Attems J, Ihara M, Kalaria RN: Vascular risk factors and neurodegeneration in ageing related dementias: Alzheimer's disease and vascular dementia. Curr Alzheimer Res 2013, 10:642-653

12. Stark SL, Roe CM, Grant EA, Hollingsworth H, Benzinger TL, Fagan AM, Buckles VD, Morris JC: Preclinical Alzheimer disease and risk of falls. Neurology 2013, 81:437-443

13. Yu JT, Xu W, Tan CC, Andrieu S, Suckling J, Evangelou E, Pan A, Zhang C, Jia J, Feng L, Kua EH, Wang YJ, Wang HF, Tan MS, Li JQ, Hou XH, Wan Y, Tan L, Mok V, Tan L, Dong Q, Touchon J, Gauthier S, Aisen PS, Vellas B: Evidence-based prevention of Alzheimer's disease: systematic review and meta-analysis of 243 observational prospective studies and 153 randomised controlled trials. J Neurol Neurosurg Psychiatry 2020, 91:1201-1209

14. Knopman DS, Gottesman RF, Sharrett AR, Tapia AL, DavisThomas S, Windham BG, Coker L, Schneider ALC, Alonso A, Coresh J, Albert MS, Mosley TH Jr: Midlife vascular risk factors and midlife cognitive status in relation to prevalence of mild cognitive impairment and dementia in later life: the Atherosclerosis Risk in Communities Study. Alzheimers Dement 2018, 14:1406-1415
15. Li J, Wang YJ, Zhang M, Xu ZQ, Gao CY, Fang CQ, Yan JC, Zhou HD, Chongqing Ageing Study Group: Vascular risk factors promote conversion from mild cognitive impairment to Alzheimer disease. Neurology 2011, 76:1485-1491

16. Carnevale D, Perrotta M, Lembo G, Trimarco B: Pathophysiological links among hypertension and Alzheimer's disease. High Blood Press Cardiovasc Prev 2016, 23:3-7

17. Nelson L, Gard P, Tabet N: Hypertension and inflammation in Alzheimer's disease: close partners in disease development and progression! J Alzheimers Dis 2014, 41:331-343

18. Petrea RE, O'Donnell A, Beiser AS, Habes M, Aparicio H, DeCarli C, Seshadri S, Romero JR: Mid to late life hypertension trends and cerebral small vessel disease in the Framingham Heart Study. Hypertension 2020, 76:707-714

19. Blevins BL, Vinters HV, Love S, Wilcock DM, Grinberg LT, Schneider JA, Kalaria RN, Katsumata Y, Gold BT, Wang DJJ, Ma SJ, Shade LMP, Fardo DW, Hartz AMS, Jicha GA, Nelson KB, Magaki SD, Schmitt FA, Teylan MA, Ighodaro ET, Phe P, Abner EL, Cykowski MD, Van Eldik LJ, Nelson PT: Brain arteriolosclerosis. Acta Neuropathol 2021, 141:1-24

20. Lennon MJ, Makkar SR, Crawford JD, Sachdev PS: Midlife hypertension and Alzheimer's disease: a systematic review and metaanalysis. J Alzheimers Dis 2019, 71:307-316

21. Gregson J, Qizilbash N, Iwagami M, Douglas I, Johnson M, Pearce N, Pocock S: Blood pressure and risk of dementia and its subtypes: a historical cohort study with long-term follow-up in 2.6 million people. Eur J Neurol 2019, 26:1479-1486

22. de Heus RAA, Olde Rikkert MGM, Tully PJ, Lawlor BA, Claassen JAHR, NILVAD Study Group: Blood pressure variability and progression of clinical Alzheimer disease. Hypertension 2019, $74: 1172-1180$

23. Ma Y, Tully PJ, Hofman A, Tzourio C: Blood pressure variability and dementia: a state-of-the-art review. Am J Hypertens 2020, 33: 1059-1066

24. Ding J, Davis-Plourde KL, Sedaghat S, Tully PJ, Wang W, Phillips C, Pase MP, Himali JJ, Gwen Windham B, Griswold M, Gottesman R, Mosley TH, White L, Guethnason V, Debette S, Beiser AS, Seshadri S, Ikram MA, Meirelles O, Tzourio C, Launer LJ: Antihypertensive medications and risk for incident dementia and Alzheimer's disease: a meta-analysis of individual participant data from prospective cohort studies. Lancet Neurol 2020, 19:61-70

25. Lebouvier T, Chen Y, Duriez P, Pasquier F, Bordet R: Antihypertensive agents in Alzheimer's disease: beyond vascular protection. Expert Rev Neurother 2020, 20:175-187

26. Walker KA, Sharrett AR, Wu A, Schneider ALC, Albert M, Lutsey PL, Bandeen-Roche K, Coresh J, Gross AL, Windham BG, Knopman DS, Power MC, Rawlings AM, Mosley TH, Gottesman RF: Association of midlife to late-life blood pressure patterns with incident dementia. JAMA 2019, 322:535-545

27. SPRINT MIND Investigators for the SPRINT Research Group, Nasrallah IM, Pajewski NM, Auchus AP, Chelune G, Cheung AK, Cleveland ML, et al: Association of intensive vs standard blood pressure control with cerebral white matter lesions. JAMA 2019, 322: $524-534$

28. Kalaria RN: Neuropathological diagnosis of vascular cognitive impairment and vascular dementia with implications for Alzheimer's disease. Acta Neuropathol 2016, 131:659-685

29. Suri S, Topiwala A, Chappell MA, Okell TW, Zsoldos E, SinghManoux A, Kivimaki M, Mackay CE, Ebmeier KP: Association of midlife cardiovascular risk profiles with cerebral perfusion at older ages. JAMA Netw Open 2019, 2:e195776

30. Petrovitch H, White LR, Izmirilian G, Ross GW, Havlik RJ, Markesbery W, Nelson J, Davis DG, Hardman J, Foley DJ, Launer LJ: Midlife blood pressure and neuritic plaques, neurofibrillary tangles, and brain weight at death: the HAAS. Honolulu-Asia aging Study. Neurobiol Aging 2000, 21:57-62 
31. Ruiz A, Pesini P, Espinosa A, Perez-Grijalba V, Valero S, SotolongoGrau O, Alegret M, Monleon I, Lafuente A, Buendia M, Ibarria M, Ruiz S, Hernandez I, San Jose I, Tarraga L, Boada M, Sarasa M: Blood amyloid beta levels in healthy, mild cognitive impairment and Alzheimer's disease individuals: replication of diastolic blood pressure correlations and analysis of critical covariates. PLoS One 2013, 8:e81334

32. Hoffman LB, Schmeidler J, Lesser GT, Beeri MS, Purohit DP, Grossman HT, Haroutunian V: Less Alzheimer disease neuropathology in medicated hypertensive than nonhypertensive persons. Neurology 2009, 72:1720-1726

33. Arvanitakis Z, Capuano AW, Lamar M, Shah RC, Barnes LL, Bennett DA, Schneider JA: Late-life blood pressure association with cerebrovascular and Alzheimer disease pathology. Neurology 2018, 91:e517-e525

34. Rupp C, Beyreuther K, Maurer K, Kins S: A presenilin 1 mutation in the first case of Alzheimer's disease: revisited. Alzheimers Dement 2014, 10:869-872

35. Carare RO, Aldea R, Agarwal N, Bacskai BJ, Bechman I, Boche D, et al: Clearance of interstitial fluid (ISF) and CSF (CLIC) group-part of Vascular Professional Interest Area (PIA): cerebrovascular disease and the failure of elimination of Amyloid-beta from the brain and retina with age and Alzheimer's disease-opportunities for therapy. Alzheimers Dement (Amst) 2020, 12:e12053

36. Fernando MS, Simpson JE, Matthews F, Brayne C, Lewis CE, Barber R, Kalaria RN, Forster G, Esteves F, Wharton SB, Shaw PJ, O'Brien JT, Ince PG: White matter lesions in an unselected cohort of the elderly: molecular pathology suggests origin from chronic hypoperfusion injury. Stroke 2006, 37:1391-1398

37. Ihara M, Polvikoski TM, Hall R, Slade JY, Perry RH, Oakley AE, Englund E, O'Brien JT, Ince PG, Kalaria RN: Quantification of myelin loss in frontal lobe white matter in vascular dementia, Alzheimer's disease, and dementia with Lewy bodies. Acta Neuropathol 2010, 119:579-589

38. Ince PG, Minett T, Forster G, Brayne C, Wharton SB, Medical Research Council Cognitive Function and Ageing Neuropathology Study: Microinfarcts in an older population-representative brain donor cohort (MRC CFAS): prevalence, relation to dementia and mobility, and implications for the evaluation of cerebral small vessel disease. Neuropathol Appl Neurobiol 2017, 43:409-418

39. Kryscio RJ, Abner EL, Nelson PT, Bennett D, Schneider J, Yu L, Hemmy LS, Lim KO, Masaki K, Cairns N, Xiong C, Woltjer R, Dodge HH, Tyas S, Fardo DW, Lou W, Wan L, Schmitt FA: The effect of vascular neuropathology on late-life cognition: results from the SMART Project. J Prev Alzheimers Dis 2016, 3:85-91

40. Kovari E, Herrmann FR, Hof PR, Bouras C: The relationship between cerebral amyloid angiopathy and cortical microinfarcts in brain ageing and Alzheimer's disease. Neuropathol Appl Neurobiol 2013, 39:498-509

41. Boyle PA, Yu L, Nag S, Leurgans S, Wilson RS, Bennett DA, Schneider JA: Cerebral amyloid angiopathy and cognitive outcomes in community-based older persons. Neurology 2015, 85:1930-1936

42. Kalaria RN, Premkumar DR, Pax AB, Cohen DL, Lieberburg I: Production and increased detection of amyloid beta protein and amyloidogenic fragments in brain microvessels, meningeal vessels and choroid plexus in Alzheimer's disease. Brain Res Mol Brain Res 1996, 35:58-68

43. Hase Y, Polvikoski TM, Firbank MJ, Craggs LJL, Hawthorne E, Platten C, Stevenson W, Deramecourt V, Ballard C, Kenny RA, Perry RH, Ince P, Carare RO, Allan LM, Horsburgh K, Kalaria RN: Small vessel disease pathological changes in neurodegenerative and vascular dementias concomitant with autonomic dysfunction. Brain Pathol 2020, 30:191-202

44. Mann DMA, Davidson YS, Robinson AC, Allen N, Hashimoto T, Richardson A, Jones M, Snowden JS, Pendleton N, Potier MC, Laquerriere A, Prasher V, Iwatsubo T, Strydom A: Patterns and severity of vascular amyloid in Alzheimer's disease associated with duplications and missense mutations in APP gene, Down syndrome and sporadic Alzheimer's disease. Acta Neuropathol 2018, 136:569-587

45. Lloyd GM, Trejo-Lopez JA, Xia Y, McFarland KN, Lincoln SJ, Ertekin-Taner N, Giasson BI, Yachnis AT, Prokop S: Prominent amyloid plaque pathology and cerebral amyloid angiopathy in APP V717I (London) carrier - phenotypic variability in autosomal dominant Alzheimer's disease. Acta Neuropathol Commun 2020, 8: 31

46. Lee S, Viqar F, Zimmerman ME, Narkhede A, Tosto G, Benzinger TL, Marcus DS, Fagan AM, Goate A, Fox NC, Cairns NJ, Holtzman DM, Buckles V, Ghetti B, McDade E, Martins RN, Saykin AJ, Masters CL, Ringman JM, Ryan NS, Forster S, Laske C, Schofield PR, Sperling RA, Salloway S, Correia S, Jack C Jr, Weiner M, Bateman RJ, Morris JC, Mayeux R, Brickman AM, Dominantly Inherited Alzheimer Network: White matter hyperintensities are a core feature of Alzheimer's disease: evidence from the Dominantly Inherited Alzheimer Network. Ann Neurol 2016, 79: 929-939

47. Heckmann JM, Low WC, de Villiers C, Rutherfoord S, Vorster A, Rao H, Morris CM, Ramesar RS, Kalaria RN: Novel presenilin 1 mutation with profound neurofibrillary pathology in an indigenous Southern African family with early-onset Alzheimer's disease. Brain 2004, 127:133-142

48. Fuller JT, Cronin-Golomb A, Gatchel JR, Norton DJ, GuzmanVelez E, Jacobs HIL, Hanseeuw B, Pardilla-Delgado E, Artola A, Baena A, Bocanegra Y, Kosik KS, Chen K, Tariot PN, Johnson K, Sperling RA, Reiman EM, Lopera F, Quiroz YT: Biological and cognitive markers of presenilin1 E280A autosomal dominant Alzheimer's disease: a comprehensive review of the Colombian kindred. J Prev Alzheimers Dis 2019, 6:112-120

49. Javanshiri K, Haglund M, Englund E: Cardiovascular disease, diabetes mellitus, and hypertension in Lewy body disease: a comparison with other dementia disorders. J Alzheimers Dis 2019, 71:851-859

50. de Bruijn RFAG, Portegies MLP, Leening MJG, Bos MJ, Hofman A, van der Lugt A, Niessen WJ, Vernooij MW, Franco OH, Koudstaal PJ, Ikram MA: Subclinical cardiac dysfunction increases the risk of stroke and dementia: the Rotterdam Study. Neurology 2015, 84:833-840

51. Schneider JA, Aggarwal NT, Barnes L, Boyle P, Bennett DA: The neuropathology of older persons with and without dementia from community versus clinic cohorts. J Alzheimers Dis 2009, 18: 691-701

52. Arvanitakis Z, Capuano AW, Leurgans SE, Bennett DA, Schneider JA: Relation of cerebral vessel disease to Alzheimer's disease dementia and cognitive function in elderly people: a crosssectional study. Lancet Neurol 2016, 15:934-943

53. Gelber RP, Launer LJ, White LR: The Honolulu-Asia Aging Study: epidemiologic and neuropathologic research on cognitive impairment. Curr Alzheimer Res 2012, 9:664-672

54. Ighodaro ET, Abner EL, Fardo DW, Lin A-L, Katsumata Y, Schmitt FA, Kryscio RJ, Jicha GA, Neltner JH, Monsell SE, Kukull WA, Moser DK, Appiah F, Bachstetter AD, Van Eldik LJ, Alzheimer's Disease Neuroimaging Initiative (ADNI), Nelson PT: Risk factors and global cognitive status related to brain arteriolosclerosis in elderly individuals. J Cereb Blood Flow Metab 2017, 37:201-216

55. Craggs LJ, Hagel C, Kuhlenbaeumer G, Borjesson-Hanson A, Andersen O, Viitanen M, Kalimo H, McLean CA, Slade JY, Hall RA, Oakley AE, Yamamoto Y, Deramecourt V, Kalaria RN: Quantitative vascular pathology and phenotyping familial and sporadic cerebral small vessel diseases. Brain Pathol 2013, 23:547-557

56. Szpak GM, Lewandowska E, Wierzba-Bobrowicz T, Bertrand E, Pasennik E, Mendel T, Stepień T, Leszczyńska A, Rafalowska J: Small cerebral vessel disease in familial amyloid and non-amyloid angiopathies: FAD-PS-1 (P117L) mutation and CADASIL. Immunohistochemical and ultrastructural studies. Folia Neuropathol 2007, 45:192-204 
57. Sabogal-Guáqueta AM, Arias-Londoño JD, Gutierrez-Vargas J, Sepulveda-Falla D, Glatzel M, Villegas-Lanau A, CardonaGómez GP: Common disbalance in the brain parenchyma of dementias: phospholipid profile analysis between CADASIL and sporadic Alzheimer's disease. Biochim Biophys Acta Mol Basis Dis 2020, 1866:165797

58. Hase Y, Ding R, Harrison G, Hawthorne E, King A, Gettings S, Platten C, Stevenson W, Craggs LJL, Kalaria RN: White matter capillaries in vascular and neurodegenerative dementias. Acta Neuropathol Commun 2019, 7:16

59. Del Bene A, Makin SD, Doubal FN, Inzitari D, Wardlaw JM: Variation in risk factors for recent small subcortical infarcts with infarct size, shape, and location. Stroke 2013, 44:3000-3006

60. Bourassa P, Tremblay C, Schneider JA, Bennett DA, Calon F: Betaamyloid pathology in human brain microvessel extracts from the parietal cortex: relation with cerebral amyloid angiopathy and Alzheimer's disease. Acta Neuropathol 2019, 137:801-823

61. Roher AE, Tyas SL, Maarouf CL, Daugs ID, Kokjohn TA, Emmerling MR, Garami Z, Belohlavek M, Sabbagh MN, Sue LI, Beach TG: Intracranial atherosclerosis as a contributing factor to Alzheimer's disease dementia. Alzheimers Dement 2011, 7:436-444

62. Wingo AP, Fan W, Duong DM, Gerasimov ES, Dammer EB, Liu Y, Harerimana NV, White B, Thambisetty M, Troncoso JC, Kim N, Schneider JA, Hajjar IM, Lah JJ, Bennett DA, Seyfried NT, Levey AI, Wingo TS: Shared proteomic effects of cerebral atherosclerosis and Alzheimer's disease on the human brain. Nat Neurosci 2020, 23:696-700

63. Prins ND, Scheltens P: White matter hyperintensities, cognitive impairment and dementia: an update. Nat Rev Neurol 2015, 11: $157-165$

64. Scott JA, Braskie MN, Tosun D, Thompson PM, Weiner M, DeCarli C, Carmichael OT, Alzheimer's Disease Neuroimaging Initiative: Cerebral amyloid and hypertension are independently associated with white matter lesions in elderly. Front Aging Neurosci 2015, 7:221

65. Roseborough A, Ramirez J, Black SE, Edwards JD: Associations between amyloid beta and white matter hyperintensities: a systematic review. Alzheimers Dement 2017, 13:1154-1167

66. Walsh P, Sudre CH, Fiford CM, Ryan NS, Lashley T, Frost C, Barnes J, Investigators: The age-dependent associations of white matter hyperintensities and neurofilament light in early- and late-stage Alzheimer's disease. Neurobiol Aging 2021, 97:10-17

67. Ramirez J, McNeely AA, Scott CJ, Stuss DT, Black SE: Subcortical hyperintensity volumetrics in Alzheimer's disease and normal elderly in the Sunnybrook Dementia Study: correlations with atrophy, executive function, mental processing speed, and verbal memory. Alzheimers Res Ther 2014, 6:49

68. Agosta F, Pievani M, Sala S, Geroldi C, Galluzzi S, Frisoni GB, Filippi M: White matter damage in Alzheimer disease and its relationship to gray matter atrophy. Radiology 2011, 258:853-863

69. Lo Buono V, Palmeri R, Corallo F, Allone C, Pria D, Bramanti P, Marino S: Diffusion tensor imaging of white matter degeneration in early stage of Alzheimer's disease: a review. Int J Neurosci 2020, 130:243-250

70. Ji F, Pasternak O, Liu S, Loke YM, Choo BL, Hilal S, Xu X, Ikram MK, Venketasubramanian N, Chen CL, Zhou J: Distinct white matter microstructural abnormalities and extracellular water increases relate to cognitive impairment in Alzheimer's disease with and without cerebrovascular disease. Alzheimers Res Ther 2017, 9:63

71. Conijn MMA, Hoogduin JM, van der Graaf Y, Hendrikse J, Luijten PR, Geerlings MI: Microbleeds, lacunar infarcts, white matter lesions and cerebrovascular reactivity - a $7 \mathrm{~T}$ study. Neuroimage 2012, 59:950-956

72. Iturria-Medina Y, Sotero RC, Toussaint PJ, Mateos-Perez JM, Evans AC, Alzheimer's Disease Neuroimaging Initiative: Early role of vascular dysregulation on late-onset Alzheimer's disease based on multifactorial data-driven analysis. Nat Commun 2016, 7:11934
73. Yew B, Nation DA, Alzheimer's Disease Neuroimaging Initiative: Cerebrovascular resistance: effects on cognitive decline, cortical atrophy, and progression to dementia. Brain 2017, 140:1987-2001

74. Korte N, Nortley R, Attwell D: Cerebral blood flow decrease as an early pathological mechanism in Alzheimer's disease. Acta Neuropathol 2020, 140:793-810

75. Gallart-Palau X, Serra A, Hase Y, Tan CF, Chen CP, Kalaria RN, Sze SK: Brain-derived and circulating vesicle profiles indicate neurovascular unit dysfunction in early Alzheimer's disease. Brain Pathol 2019, 29:593-605

76. Jefferson AL, Liu D, Gupta DK, Pechman KR, Watchmaker JM, Gordon EA, Rane S, Bell SP, Mendes LA, Davis LT, Gifford KA, Hohman TJ, Wang TJ, Donahue MJ: Lower cardiac index levels relate to lower cerebral blood flow in older adults. Neurology 2017, 89:2327-2334

77. Nation DA, Sweeney MD, Montagne A, Sagare AP, D’Orazio LM, Pachicano M, Sepehrband F, Nelson AR, Buennagel DP, Harrington MG, Benzinger TLS, Fagan AM, Ringman JM, Schneider LS, Morris JC, Chui HC, Law M, Toga AW, Zlokovic BV: Blood-brain barrier breakdown is an early biomarker of human cognitive dysfunction. Nat Med 2019, 25:270-276

78. Benzinger TL, Blazey T, Jack CR Jr, Koeppe RA, Su Y, Xiong C, et al: Regional variability of imaging biomarkers in autosomal dominant Alzheimer's disease. Proc Natl Acad Sci U S A 2013, 110: E4502-E4509

79. Montagne A, Nation DA, Sagare AP, Barisano G, Sweeney MD, Chakhoyan A, Pachicano M, Joe E, Nelson AR, D’Orazio LM, Buennagel DP, Harrington MG, Benzinger TLS, Fagan AM, Ringman JM, Schneider LS, Morris JC, Reiman EM, Caselli RJ, Chui HC, Tcw J, Chen Y, Pa J, Conti PS, Law M, Toga AW, Zlokovic BV: APOE4 leads to blood-brain barrier dysfunction predicting cognitive decline. Nature 2020, 581:71-76

80. Johnson KA, Lopera F, Jones K, Becker A, Sperling R, Hilson J, Londono J, Siegert I, Arcos M, Moreno S, Madrigal L, Ossa J, Pineda N, Ardila A, Roselli M, Albert MS, Kosik KS, Rios A: Presenilin-1-associated abnormalities in regional cerebral perfusion. Neurology 2001, 56:1545-1551

81. McDade E, Kim A, James J, Sheu LK, Kuan DC, Minhas D, Gianaros PJ, Ikonomovic S, Lopez O, Snitz B, Price J, Becker J, Mathis C, Klunk W: Cerebral perfusion alterations and cerebral amyloid in autosomal dominant Alzheimer disease. Neurology 2014, 83:710-717

82. Ostergaard L, Engedal TS, Moreton F, Hansen MB, Wardlaw JM, Dalkara T, Markus HS, Muir KW: Cerebral small vessel disease: capillary pathways to stroke and cognitive decline. J Cereb Blood Flow Metab 2016, 36:302-325

83. Nakajima M, Yuasa S, Ueno M, Takakura N, Koseki H, Shirasawa T: Abnormal blood vessel development in mice lacking presenilin-1. Mech Dev 2003, 120:657-667

84. Englund E: Neuropathology of white matter changes in Alzheimer's disease and vascular dementia. Dement Geriatr Cogn Disord 1998, 1(9 Suppl):6-12

85. Hase Y, Horsburgh K, Ihara M, Kalaria RN: White matter degeneration in vascular and other ageing-related dementias. J Neurochem 2018, 144:617-633

86. Ding R, Hase Y, Ameen-Ali KE, Ndung'u M, Stevenson W, Barsby J, Gourlay R, Akinyemi T, Akinyemi R, Uemura MT, Polvikoski T, Mukaetova-Ladinska E, Ihara M, Kalaria RN: Loss of capillary pericytes and the blood-brain barrier in white matter in poststroke and vascular dementias and Alzheimer's disease. Brain Pathol 2020, 30:1087-1101

87. Wong SM, Jansen JFA, Zhang CE, Hoff EI, Staals J, van Oostenbrugge RJ, Backes WH: Blood-brain barrier impairment and hypoperfusion are linked in cerebral small vessel disease. Neurology 2019, 92:e1669-e1677

88. Weller RO, Hawkes CA, Kalaria RN, Werring DJ, Carare RO: White matter changes in dementia: role of impaired drainage of interstitial fluid. Brain Pathol 2015, 25:63-78 
89. Araque Caballero MÁ, Suárez-Calvet M, Duering M, Franzmeier N, Benzinger T, Fagan AM, Bateman RJ, Jack CR, Levin J, Dichgans M, Jucker M, Karch C, Masters CL, Morris JC, Weiner M, Rossor M, Fox NC, Lee J-H, Salloway S, Danek A, Goate A, Yakushev I, Hassenstab J, Schofield PR, Haass C, Ewers M: White matter diffusion alterations precede symptom onset in autosomal dominant Alzheimer's disease. Brain 2018, 141:3065-3080

90. Erten-Lyons D, Woltjer R, Kaye J, Mattek N, Dodge HH, Green S, Tran H, Howieson DB, Wild K, Silbert LC: Neuropathologic basis of white matter hyperintensity accumulation with advanced age. Neurology 2013, 81:977-983

91. Wu Y, Ma Y, Liu Z, Geng Q, Chen Z, Zhang Y: Alterations of myelin morphology and oligodendrocyte development in early stage of Alzheimer's disease mouse model. Neurosci Lett 2017, 642: 102-106

92. Bello-Chavolla OY, Antonio-Villa NE, Vargas-Vázquez A, ÁvilaFunes JA, Aguilar-Salinas CA: Pathophysiological mechanisms linking type 2 diabetes and dementia: review of evidence from clinical, translational and epidemiological research. Curr Diabetes Rev 2019, 15:456-470

93. Jefferson AL, Cambronero FE, Liu D, Moore EE, Neal JE, Terry JG, Nair S, Pechman KR, Rane S, Davis LT, Gifford KA, Hohman TJ, Bell SP, Wang TJ, Beckman JA, Carr JJ: Higher aortic stiffness is related to lower cerebral blood flow and preserved cerebrovascular reactivity in older adults. Circulation 2018, 138:1951-1962

94. Langbaum JB, Chen K, Launer LJ, Fleisher AS, Lee W, Liu X, Protas HD, Reeder SA, Bandy D, Yu M, Caselli RJ, Reiman EM: Blood pressure is associated with higher brain amyloid burden and lower glucose metabolism in healthy late middle-age persons. Neurobiol Aging 2012, 33:e11-e19

95. Toledo JB, Toledo E, Weiner MW, Jack CR Jr, Jagust W, Lee VM, Shaw LM, Trojanowski JQ, Alzheimer's Disease Neuroimaging Initiative: Cardiovascular risk factors, cortisol, and amyloid-beta deposition in Alzheimer's Disease Neuroimaging Initiative. Alzheimers Dement 2012, 8:483-489

96. Hughes TM, Kuller LH, Barinas-Mitchell EJ, Mackey RH, McDade EM, Klunk WE, Aizenstein HJ, Cohen AD, Snitz BE, Mathis CA, Dekosky ST, Lopez OL: Pulse wave velocity is associated with beta-amyloid deposition in the brains of very elderly adults. Neurology 2013, 81:1711-1718

97. Hughes TM, Wagenknecht LE, Craft S, Mintz A, Heiss G, Palta P, Wong D, Zhou Y, Knopman D, Mosley TH, Gottesman RF: Arterial stiffness and dementia pathology: Atherosclerosis Risk in Communities (ARIC)-PET study. Neurology 2018, 90:e1248-e1256

98. Shi Y, Thrippleton MJ, Blair GW, Dickie DA, Marshall I, Hamilton I, Doubal FN, Chappell F, Wardlaw JM: Small vessel disease is associated with altered cerebrovascular pulsatility but not resting cerebral blood flow. J Cereb Blood Flow Metab 2020, 40:85-99

99. van Opstal AM, van Rooden S, van Harten T, Ghariq E, Labadie G, Fotiadis P, Gurol ME, Terwindt GM, Wermer MJH, van Buchem MA, Greenberg SM, van der Grond J: Cerebrovascular function in presymptomatic and symptomatic individuals with hereditary cerebral amyloid angiopathy: a case-control study. Lancet Neurol 2017, 16:115-122

100. Toth P, Tarantini S, Csiszar A, Ungvari Z: Functional vascular contributions to cognitive impairment and dementia: mechanisms and consequences of cerebral autoregulatory dysfunction, endothelial impairment, and neurovascular uncoupling in aging. Am J Physiol Heart Circ Physiol 2017, 312:H1-H20

101. van Beek AH, Lagro J, Olde-Rikkert MG, Zhang R, Claassen JA: Oscillations in cerebral blood flow and cortical oxygenation in Alzheimer's disease. Neurobiol Aging 2012, 33:e21-e31

102. Zazulia AR, Videen TO, Morris JC, Powers WJ: Autoregulation of cerebral blood flow to changes in arterial pressure in mild Alzheimer's disease. J Cereb Blood Flow Metab 2010, 30: 1883-1889
103. Zhang L, Pasha EP, Liu J, Xing C-Y, Cardim D, Tarumi T, Womack K, Hynan LS, Cullum CM, Zhang R: Steady-state cerebral autoregulation in older adults with amnestic mild cognitive impairment: linear mixed model analysis. J Appl Physiol (1985) 2020, 129: $377-385$

104. Greenberg SM, Bacskai BJ, Hernandez-Guillamon M, Pruzin J, Sperling R, van Veluw SJ: Cerebral amyloid angiopathy and Alzheimer disease - one peptide, two pathways. Nat Rev Neurol 2020, 16:30-42

105. Thal DR, von Arnim C, Griffin WS, Yamaguchi H, Mrak RE, Attems J, Upadhaya AR: Pathology of clinical and preclinical Alzheimer's disease. Eur Arch Psychiatry Clin Neurosci 2013, 2(263 Suppl):S137-S145

106. Reinert J, Richard BC, Klafki HW, Friedrich B, Bayer TA, Wiltfang J, Kovacs GG, Ingelsson M, Lannfelt L, Paetau A, Bergquist J, Wirths O: Deposition of C-terminally truncated Abeta species Abeta37 and Abeta39 in Alzheimer's disease and transgenic mouse models. Acta Neuropathol Commun 2016, 4:24

107. Giaccone G, Morbin M, Moda F, Botta M, Mazzoleni G, Uggetti A, Catania M, Moro ML, Redaelli V, Spagnoli A, Rossi RS, Salmona M, Di Fede G, Tagliavini F: Neuropathology of the recessive A673V APP mutation: Alzheimer disease with distinctive features. Acta Neuropathol 2010, 120:803-812

108. Huang CY, Hsiao IT, Lin KJ, Huang KL, Fung HC, Liu CH, Chang TY, Weng YC, Hsu WC, Yen TC, Huang CC: Amyloid PET pattern with dementia and amyloid angiopathy in Taiwan familial AD with D678H APP mutation. J Neurol Sci 2019, 398:107-116

109. Cras P, van Harskamp F, Hendriks L, Ceuterick C, van Duijn CM, Stefanko SZ, Hofman A, Kros JM, Van Broeckhoven C, Martin JJ: Presenile Alzheimer dementia characterized by amyloid angiopathy and large amyloid core type senile plaques in the APP 692Ala-> Gly mutation. Acta Neuropathol 1998, 96:253-260

110. Tagliavini F, Rossi G, Padovani A, Magoni M, Andora G, Sgarzi M, Bizzi A, Savoiardo M, Carella F, Morbin M, Giaccone G, Bugiani O: A new $\beta$ PP mutation related to hereditary cerebral haemorrhage. Alzheimer's Rep 1999, 2:S28

111. Timmers WF, Tagliavini F, Haan J, Frangione B: Parenchymal preamyloid and amyloid deposits in the brains of patients with hereditary cerebral hemorrhage with amyloidosis-Dutch type. Neurosci Lett 1990, 118:223-226

112. Mok T, Chalissery AJ, Byrne S, Costelloe L, Galvin L, Vinters HV, Farrell MA, Brett FM, Moroney JT: Familial cerebral amyloid angiopathy due to the Iowa mutation in an Irish family. Can J Neurol Sci 2014, 41:512-517

113. Armstrong J, Boada M, Rey MJ, Vidal N, Ferrer I: Familial Alzheimer disease associated with A713T mutation in APP. Neurosci Lett 2004, 370:241-243

114. Kumar-Singh S, De Jonghe C, Cruts M, Kleinert R, Wang R, Mercken M, De Strooper B, Vanderstichele H, Lofgren A, Vanderhoeven I, Backhovens H, Vanmechelen E, Kroisel PM, Van Broeckhoven C: Nonfibrillar diffuse amyloid deposition due to a gamma(42)-secretase site mutation points to an essential role for $\mathrm{N}$ truncated A beta(42) in Alzheimer's disease. Hum Mol Genet 2000, 9:2589-2598

115. Ghetti B, Murrell J, Benson MD, Farlow MR: Spectrum of amyloid beta-protein immunoreactivity in hereditary Alzheimer disease with a guanine to thymine missense change at position 1924 of the APP gene. Brain Res 1992, 571:133-139

116. Mann DM, Jones D, Snowden JS, Neary D, Hardy J: Pathological changes in the brain of a patient with familial Alzheimer's disease having a missense mutation at codon 717 in the amyloid precursor protein gene. Neurosci Lett 1992, 137:225-228

117. Lantos PL, Luthert PJ, Hanger D, Anderton BH, Mullan M, Rossor M: Familial Alzheimer's disease with the amyloid precursor protein position 717 mutation and sporadic Alzheimer's disease have the same cytoskeletal pathology. Neurosci Lett 1992, 137:221-224 
118. Ghetti B, Hake AM, Murrell JR, Epperson F, Farlow MR, Vidal R, Spina S: Familial Alzheimer's disease associated with the V7171 amyloid precursor protein gene mutation: neuropathological characterization. Alzheimers Dement (Amst) 2008, 4:221

119. Steiner H, Revesz T, Neumann M, Romig H, Grim MG, Pesold B, Kretzschmar HA, Hardy J, Holton JL, Baumeister R, Houlden H, Haass C: A pathogenic presenilin-1 deletion causes abberrant Abeta 42 production in the absence of congophilic amyloid plaques. J Biol Chem 2001, 276:7233-7239

120. Lanoiselée H-M, Nicolas G, Wallon D, Rovelet-Lecrux A, Lacour M, Rousseau S, et al, collaborators of the CNR-MAJ project: APP, PSEN1, and PSEN2 mutations in early-onset Alzheimer disease: a genetic screening study of familial and sporadic cases. PLoS Med 2017, 14:e1002270

121. Queralt R, Ezquerra M, Lleo A, Castellvi M, Gelpi J, Ferrer I, Acarin N, Pasarin L, Blesa R, Oliva R: A novel mutation (V89L) in the presenilin 1 gene in a family with early onset Alzheimer's disease and marked behavioural disturbances. J Neurol Neurosurg Psychiatry 2002, 72:266-269

122. Singleton AB, Hall R, Ballard CG, Perry RH, Xuereb JH, Rubinsztein DC, Tysoe C, Matthews P, Cordell B, Kumar-Singh S, De Jonghe C, Cruts M, van Broeckhoven C, Morris CM: Pathology of early-onset Alzheimer's disease cases bearing the Thr113-114ins presenilin-1 mutation. Brain 2000, 123:2467-2474

123. Finckh U, Kuschel C, Anagnostouli M, Patsouris E, Pantes GV, Gatzonis S, Kapaki E, Davaki P, Lamszus K, Stavrou D, Gal A: Novel mutations and repeated findings of mutations in familial Alzheimer disease. Neurogenetics 2005, 6:85-89

124. Sutovsky S, Smolek T, Turcani P, Petrovic R, Brandoburova P, Jadhav S, Novak P, Attems J, Zilka N: Neuropathology and biochemistry of early onset familial Alzheimer's disease caused by presenilin-1 missense mutation Thr116Asn. J Neural Transm (Vienna) 2018, 125:965-976

125. Lladó A, Sánchez-Valle R, Rey MJ, Mercadal P, Almenar C, LópezVillegas D, Fortea J, Molinuevo JL: [New mutation in the PSEN1 (E120G) gene associated with early onset Alzheimer's disease]. Spanish. Neurologia 2010, 25:13-16

126. Natelson Love M, Clark DG, Cochran JN, Den Beste KA, Geldmacher DS, Benzinger TL, Gordon BA, Morris JC, Bateman RJ, Roberson ED: Clinical, imaging, pathological, and biochemical characterization of a novel presenilin 1 mutation (N135Y) causing Alzheimer's disease. Neurobiol Aging 2017, 49:216.e7-216.e13

127. Arber C, Lovejoy C, Harris L, Willumsen N, Alatza A, Casey JM, Lines G, Kerins C, Mueller AK, Zetterberg H, Hardy J, Ryan NS, Fox NC, Lashley T, Wray S: Familial Alzheimer's disease mutations in PSEN1 lead to premature human stem cell neurogenesis. Cell Rep 2021, 34:108615

128. Gallo M, Marcello N, Curcio SA, Colao R, Geracitano S, Bernardi L, Anfossi M, Puccio G, Frangipane F, Clodomiro A, Mirabelli M, Vasso F, Smirne N, Muraca G, Di Lorenzo R, Maletta R, Ghidoni E, Bugiani O, Tagliavini F, Giaccone G, Bruni AC: A novel pathogenic PSEN1 mutation in a family with Alzheimer's disease: phenotypical and neuropathological features. J Alzheimers Dis 2011, 25:425-431

129. Bertoli Avella AM, Marcheco Teruel B, Llibre Rodriguez JJ, Gomez Viera N, Borrajero Martinez I, Severijnen EA, Joosse M, van Duijn CM, Heredero Baute L, Heutink P: A novel presenilin $1 \mathrm{mu}-$ tation (L174 M) in a large Cuban family with early onset Alzheimer disease. Neurogenetics 2002, 4:97-104

130. Yasuda M, Maeda K, Ikejiri Y, Kawamata T, Kuroda S, Tanaka C: A novel missense mutation in the presenilin-1 gene in a familial Alzheimer's disease pedigree with abundant amyloid angiopathy. Neurosci Lett 1997, 232:29-32

131. Ryan NS, Lashley T, Revesz T, Dantu K, Fox NC, Morris HR: Spontaneous ARIA (amyloid-related imaging abnormalities) and cerebral amyloid angiopathy related inflammation in presenilin 1-associated familial Alzheimer's disease. J Alzheimers Dis 2015, 44:1069-1074
132. Takao M, Ghetti B, Hayakawa I, Ikeda E, Fukuuchi Y, Miravalle L, Piccardo P, Murrell JR, Glazier BS, Koto A: A novel mutation (G217D) in the Presenilin 1 gene (PSEN1) in a Japanese family: presenile dementia and parkinsonism are associated with cotton wool plaques in the cortex and striatum. Acta Neuropathol 2002, 104: 155-170

133. Smith MJ, Gardner RJ, Knight MA, Forrest SM, Beyreuther K, Storey E, McLean CA, Cotton RG, Cappal R, Masters CL: Earlyonset Alzheimer's disease caused by a novel mutation at codon 219 of the presenilin-1 gene. Neuroreport 1999, 10:503-507

134. Piaceri I, Chiari A, Galli C, Bagnoli S, Ferrari C, Saavedra ST, Molinari MA, Vinceti G, Sorbi S, Nacmias B: Incomplete penetrance in familial Alzheimer's disease with PSEN1 Ala260Gly mutation. Neurol Sci 2020, 41:2263-2266

135. Farlow MR, Murrell JR, Hulette CM, Ghetti B: Hereditary lateral sclerosis and Alzheimer disease associated with mutation at codon 261 of the presenilin 1 (PS1) gene. Neurobiol Aging 2000, 21:62

136. Akatsu H, Yamagata H, Wake A, Watanabe I, Kimura N, Kamada K, Miyazaki T, Tanabe H, Miki T, Yamamoto T, Hori A, Mimuro M, Yoshida M, Hashizume Y: The first autopsy case report of familial Alzheimer's disease (AD) associated with a mutation at G266S in the presenilin 1 (PSEN1) gene. Alzheimers Dement (Amst) 2008, 4: T578

137. Ringman JM, Monsell S, Ng DW, Zhou Y, Nguyen A, Coppola G, Van Berlo V, Mendez MF, Tung S, Weintraub S, Mesulam M-M, Bigio EH, Gitelman DR, Fisher-Hubbard AO, Albin RL, Vinters HV: Neuropathology of autosomal dominant Alzheimer disease in the National Alzheimer Coordinating Center database. J Neuropathol Exp Neurol 2016, 75:284-290

138. Sánchez-Valle R, Lladó A, Ezquerra M, Rey MJ, Rami L, Molinuevo JL: A novel mutation in the PSEN1 gene (L286P) associated with familial early-onset dementia of Alzheimer type and lobar haematomas. Eur J Neurol 2007, 14:1409-1412

139. Gómez-Isla T, Wasco W, Pettingell WP, Gurubhagavatula S, Schmidt SD, Jondro PD, McNamara M, Rodes LA, DiBlasi T, Growdon WB, Seubert P, Schenk D, Growdon JH, Hyman BT, Tanzi RE: A novel presenilin-1 mutation: increased beta-amyloid and neurofibrillary changes. Ann Neurol 1997, 41:809-813

140. Kwok JB, Halliday GM, Brooks WS, Dolios G, Laudon H, Murayama O, Hallupp M, Badenhop RF, Vickers J, Wang R, Naslund J, Takashima A, Gandy SE, Schofield PR: Presenilin-1 mutation L271V results in altered exon 8 splicing and Alzheimer's disease with non-cored plaques and no neuritic dystrophy. J Biol Chem 2003, 278:6748-6754

141. Jimenez-Escrig A, Rabano A, Guerrero C, Simon J, Barquero MS, Güell I, Ginestal RC, Montero T, Orensanz L: New V272A presenilin 1 mutation with very early onset subcortical dementia and parkinsonism. Eur J Neurol 2004, 11:663-669

142. Dinkel F, Trujillo-Rodriguez D, Villegas A, Streffer J, Mercken M, Lopera F, Glatzel M, Sepulveda-Falla D: Decreased deposition of beta-amyloid 1-38 and increased deposition of beta-amyloid 1-42 in brain tissue of Presenilin-1 E280A familial Alzheimer's disease patients. Front Aging Neurosci 2020, 12:220

143. O'Riordan S, McMonagle P, Janssen JC, Fox NC, Farrell M, Collinge J, Rossor MN, Hutchinson M: Presenilin-1 mutation (E280G), spastic paraparesis, and cranial MRI white-matter abnormalities. Neurology 2002, 59:1108-1110

144. Dermaut B, Kumar-Singh S, De Jonghe C, Cruts M, Lofgren A, Lubke U, Cras P, Dom R, De Deyn PP, Martin JJ, Van Broeckhoven C: Cerebral amyloid angiopathy is a pathogenic lesion in Alzheimer's disease due to a novel presenilin 1 mutation. Brain 2001, 124:2383-2392

145. Bagyinszky E, Youn YC, An SS, Kim S: Mutations, associated with early-onset Alzheimer's disease, discovered in Asian countries. Clin Interv Aging 2016, 11:1467-1488

146. Crook R, Verkkoniemi A, Perez-Tur J, Mehta N, Baker M, Houlden H, Farrer M, Hutton M, Lincoln S, Hardy J, Gwinn K, 
Somer M, Paetau A, Kalimo H, Ylikoski R, Poyhonen M, Kucera S, Haltia M: A variant of Alzheimer's disease with spastic paraparesis and unusual plaques due to deletion of exon 9 of presenilin 1. Nat Med 1998, 4:452-455

147. Yasuda M, Maeda S, Kawamata T, Tamaoka A, Yamamoto Y, Kuroda S, Maeda K, Tanaka C: Novel presenilin-1 mutation with widespread cortical amyloid deposition but limited cerebral amyloid angiopathy. J Neurol Neurosurg Psychiatry 2000, 68:220-223

148. Miki T, Yokota O, Haraguchi T, Ikeuchi T, Zhu B, Takenoshita S, Terada S, Yamada N: Young adult-onset, very slowly progressive cognitive decline with spastic paraparesis in Alzheimer's disease with cotton wool plaques due to a novel presenilin1 G417S mutation. Acta Neuropathol Commun 2019, 7:19

149. Ishikawa A, Piao YS, Miyashita A, Kuwano R, Onodera O, Ohtake H, Suzuki M, Nishizawa M, Takahashi H: A mutant PSEN1 causes dementia with Lewy bodies and variant Alzheimer's disease. Ann Neurol 2005, 57:429-434

150. Piscopo P, Marcon G, Piras MR, Crestini A, Campeggi LM, Deiana E, Cherchi R, Tanda F, Deplano A, Vanacore N, Tagliavini F, Pocchiari M, Giaccone G, Confaloni A: A novel PSEN2 mutation associated with a peculiar phenotype. Neurology 2008, 70:1549-1554

151. Braggin JE, Bucks SA, Course MM, Smith CL, Sopher B, Osnis L, Shuey KD, Domoto-Reilly K, Caso C, Kinoshita C, Scherpelz KP, Cross C, Grabowski T, Nik SHM, Newman M, Garden GA, Leverenz JB, Tsuang D, Latimer C, Gonzalez-Cuyar LF, Keene CD, Morrison RS, Rhoads K, Wijsman EM, Dorschner MO, Lardelli M, Young JE, Valdmanis PN, Bird TD, Jayadev S: Alternative splicing in a presenilin 2 variant associated with Alzheimer disease. Ann Clin Transl Neurol 2019, 6:762-777

152. Jayadev S, Leverenz JB, Steinbart E, Stahl J, Klunk W, Yu CE, Bird TD: Alzheimer's disease phenotypes and genotypes associated with mutations in presenilin 2. Brain 2010, 133:1143-1154

153. Wells JL, Pasternak SH: Case report of a 63-year-old patient with Alzheimer disease and a novel presenilin 2 mutation. Alzheimer Dis Assoc Disord 2019, 33:166-169
154. Suarez MCF, Brusco I, Damasso C, Olivar N, Morelli L, Russo G: Heterozygous APP A713T mutation carrier with inflammatoy amyloid angiopathy and family history of Alzheimer's disease: first case in Argentina. J Neurol Stroke 2019, 9:86-89

155. Gkanatsiou E, Portelius E, Toomey CE, Blennow K, Zetterberg H, Lashley T, Brinkmalm G: A distinct brain beta amyloid signature in cerebral amyloid angiopathy compared to Alzheimer's disease. Neurosci Lett 2019, 701:125-131

156. Okamoto Y, Ihara M, Fujita Y, Ito H, Takahashi R, Tomimoto H: Cortical microinfarcts in Alzheimer's disease and subcortical vascular dementia. Neuroreport 2009, 20:990-996

157. Okamoto Y, Yamamoto T, Kalaria RN, Senzaki H, Maki T, Hase Y, Kitamura A, Washida K, Yamada M, Ito $\mathrm{H}$, Tomimoto $\mathrm{H}$, Takahashi R, Ihara M: Cerebral hypoperfusion accelerates cerebral amyloid angiopathy and promotes cortical microinfarcts. Acta Neuropathol 2012, 123:381-394

158. Lee S, Zimmerman ME, Narkhede A, Nasrabady SE, Tosto G, Meier IB, Benzinger TLS, Marcus DS, Fagan AM, Fox NC, Cairns NJ, Holtzman DM, Buckles V, Ghetti B, McDade E, Martins RN, Saykin AJ, Masters CL, Ringman JM, Frster S, Schofield PR, Sperling RA, Johnson KA, Chhatwal JP, Salloway S, Correia S, Jack CR Jr, Weiner M, Bateman RJ, Morris JC, Mayeux R, Brickman AM, Dominantly Inherited Alzheimer Network: White matter hyperintensities and the mediating role of cerebral amyloid angiopathy in dominantly-inherited Alzheimer's disease. PLoS One 2018, 13:e195838

159. McCreary CR, Beaudin AE, Subotic A, Zwiers AM, Alvarez A, Charlton A, Goodyear BG, Frayne R, Smith EE: Cross-sectional and longitudinal differences in peak skeletonized white matter mean diffusivity in cerebral amyloid angiopathy. Neuroimage Clin 2020, 27:102280

160. Ramirez J, McNeely AA, Scott CJM, Masellis M, Black SE, Alzheimer's Disease Neuroimaging Initiative: White matter hyperintensity burden in elderly cohort studies: the Sunnybrook Dementia Study, Alzheimer's Disease Neuroimaging Initiative, and Three-City Study. Alzheimers Dement 2016, 12:203-210 